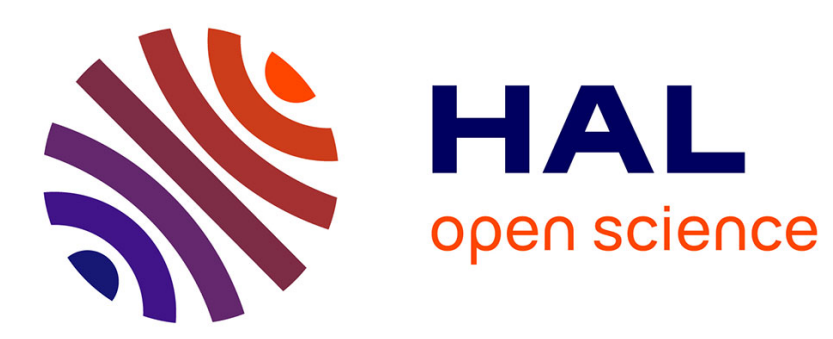

\title{
Chlorophyll signatures and nutrient cycles in the Mediterranean Sea: a model sensitivity study to nitrogen and phosphorus atmospheric inputs
}

\author{
M. Pacciaroni, G. Crispi
}

\section{- To cite this version:}

M. Pacciaroni, G. Crispi. Chlorophyll signatures and nutrient cycles in the Mediterranean Sea: a model sensitivity study to nitrogen and phosphorus atmospheric inputs. Biogeosciences Discussions, 2007, 4 (2), pp.909-959. hal-00297880

\section{HAL Id: hal-00297880 \\ https://hal.science/hal-00297880}

Submitted on 27 Mar 2007

HAL is a multi-disciplinary open access archive for the deposit and dissemination of scientific research documents, whether they are published or not. The documents may come from teaching and research institutions in France or abroad, or from public or private research centers.
L'archive ouverte pluridisciplinaire HAL, est destinée au dépôt et à la diffusion de documents scientifiques de niveau recherche, publiés ou non, émanant des établissements d'enseignement et de recherche français ou étrangers, des laboratoires publics ou privés. 
Biogeosciences Discuss., 4, 909-959, 2007

www.biogeosciences-discuss.net/4/909/2007/

(c) Author(s) 2007. This work is licensed

under a Creative Commons License.

Biogeosciences Discussions is the access reviewed discussion forum of Biogeosciences
Biogeosciences

Discussions

BGD

4, 909-959, 2007

Mediterranean

sensitivity to

atmospheric inputs

M. Pacciaroni and

G. Crispi

\section{Chlorophyll signatures and nutrient cycles in the Mediterranean Sea: a model sensitivity study to nitrogen and phosphorus atmospheric inputs}

M. Pacciaroni and G. Crispi

Istituto Nazionale di Oceanografia e di Geofisica Sperimentale, Trieste, Italy

Received: 14 March 2007 - Accepted: 19 March 2007 - Published: 27 March 2007

Correspondence to: M. Pacciaroni (mpacciaroni@ogs.trieste.it)

Title Page

Abstract

Introduction

Conclusions

References

Tables

Figures

14

4

Back

Full Screen / Esc

Printer-friendly Version

Interactive Discussion 


\section{Abstract}

In this work, the relative importance of nitrogen and phosphorus, considered as external loads, on Mediterranean biogeochemical cycles is evaluated. Biomass concentrations are analysed considering the steady state response of the three-dimensional

5 ECHYM model to three nitrogen and phosphorus atmospheric depositions, considered as continuous in time.

After reaching stationary evolutions, chlorophyll surficial maps and vertical transects are compared with existing datasets, showing a good agreement at their large scale sampling.

10 The distributions of nutrients within the biochemical compartments are analysed, highlighting, inside the Mediterranean oligotrophic environment, the role played by ultraplankton, the smaller phytoplankton compartment. For all the three different atmospheric loads, western primary production estimation is about twice than that in the eastern basin, while western secondary production is about three times the eastern 5 one.

This numerical exercise suggests that the Eastern Mediterranean, cycling at low nutrient sill, is eventually pushed toward an higher nutrient depletion, when loading new nitrogen and phosphorus.

\section{Introduction}

20 The oligotrophy of the Mediterranean Sea is explainable as a response to the negative thermohaline circulation (Redfield et al., 1963). The inverse estuarine circulation of the whole basin determines a negative budget for nutrients at the Gibraltar Strait (Coste et al., 1988), since there, nutrient-poor surface water is imported from the Atlantic Ocean and relatively nutrient-rich intermediate water is exported. Thus the detailed threedimensional hydrodynamics of the entire basin, coupled to the main biogeochemical dynamics, must be taken into account to resolve the Mediterranean ecosystem vari-
BGD

4, 909-959, 2007

Mediterranean sensitivity to atmospheric inputs

M. Pacciaroni and G. Crispi

Title Page

Abstract Introduction

Conclusions References

Tables Figures

14

4

Back

Close

Full Screen / Esc

Printer-friendly Version

Interactive Discussion 
ability.

Due to net evaporation in the Mediterranean, the inverse estuarine circulation exBGD plains with the exogenous inputs only the nutrient-depletion in nitrogen and phosphorus, with respect to the Atlantic Ocean, of the deeper layers of the Mediterranean. That 5 is not the case for the oligotrophic status. If biogeochemical cycle were turned off, upper layer concentrations should increase up to values of the same order of deeper layers, greater in the Eastern than in the Western Mediterranean (Crispi et al., 2001).

As a matter of fact, only taking into account realistic fluxes of the biogenic matter toward deeper layers, the oligotrophy of the basin emerges as a clear feature in terms 10 both of nitrogen and of phosphorus obtaining nutrient-poor deep layer concentrations in the eastern basin with respect to the western relatively richer ones, as observed in experimental studies.

Phytoplankton growth depends on the above-mentioned nutrient conditions. Chlorophyll concentrations remain high in the upper layer and coincide with nutrient depletion 15 (Lefevre et al., 1997). The nutrient-depleted surface layer is separated from a layer of abundant nutrients, at some distance below the euphotic depth, by a nutricline, layer in which nutrient concentrations increase rapidly with depth. Therefore, depending on light intensity at the surface and the turbidity of the water, the displacements of nutricline and pycnocline determine abundance and productivity of phytoplankton.

20 Zooplankton is typically concentrated within the euphotic zone, but because of sinking and diel vertical migration of some species into and outside from the euphotic zone, organic matter is supplied and various types of zooplankton can be found at deeper layers. This depth range can displace the grazers from the near surface lighted waters where the phytoplankton grows, to deeper environments (Kovalev et al., 1999).

25 Therefore, understanding the mechanisms of Mediterranean ecosystems is connected to physical, chemical and biological aspects of the photic and aphotic zones. The aim of this paper is to clear in which way nutrient availability influences the structure and functioning of the euphotic food web and the export of matter.

The importance of external loads cannot easily be underestimated; nevertheless

Mediterranean sensitivity to atmospheric inputs

M. Pacciaroni and G. Crispi

Title Page

Abstract Introduction

Conclusions

Tables

References

Figures

14

4

Back

Full Screen / Esc

Printer-friendly Version

Interactive Discussion 
it results, from an experimental point of view, difficult to represent detailed regional atmospheric inputs in the Mediterranean Sea. In this work, western and eastern nitrogen and phosphorus deposition data are analysed considering different intensities, according with various authors: they are applied in this ecomodel differentiating among 5 western, central and eastern areas of the basin.

Considering three evolutions guided by the same hydrodynamics, with different nutrient loads at surface, a sensitivity analysis of the ecological model is carried out, observing the major biotic compartment responses and particularly the primary and secondary productions.

10 The Mediterranean Sea has been studied from the ecological point of view by means of regional models (Civitarese et al., 1996; Tusseau-Vuillemin et al., 1998; Lévy et al., 1999; Zavatarelli et al., 2000; Petihakis et al., 2002), as well as basin descriptions (Crise et al., 1998). Biogeochemical setups descriptions of different complexities have been proposed in terms of: few variables to give geochemical picture of the ecosys15 tem evolution; aggregated compartments following both carbon and nutrient cycles; ecosystem models more detailed in term of individual-based functional relations.

The results of the Joint Global Ocean Flux Study Program suggest that reasonable resolution of the trophic web for this purpose is obtained with a good parameterization of the effective processes in the lower trophic levels, reducing the higher trophic ones to the pressure of only one generalized secondary producer, which closes the ecosystem dynamics. This choice gives raise to systems with eight or nine compartments, like those applied for depicting the high export carbon fluxes related to high nitrogen fixation versus the high dissolved inorganic carbon with low nitrogen fixation in Atlantic Ocean (Hood et al., 2001); or like those used for studying the high nitrate concentrations contrasting the low silicates in the equatorial Pacific Ocean (Chai et al., 2002).

Being the motivation of this work the resolution of the conveyor belt role, from one side, and the interplay among the different nutrient limitations and the top-down control, from the other, ECHYM model is applied. This three-dimensional ecomodel of the pelagic Mediterranean takes into account nitrogen and phosphorus cycles, including

BGD

4, 909-959, 2007

Mediterranean sensitivity to atmospheric inputs

M. Pacciaroni and G. Crispi

Title Page

Abstract Introduction

Conclusions

Tables

References

Figures

14

4

Back

Full Screen / Esc

Printer-friendly Version

Interactive Discussion 
two primary producers, herbivorous zooplankton, and detritus.

Many dynamical processes which are fundamental to the World Ocean circulation also occur within the Mediterranean Sea, such as deep convection cells (completely analogous to the North Atlantic Deep Water cell), with convective sites in both the 5 western and eastern basins. Thus the Mediterranean Sea provides a laboratory basin also for general circulation and related ecological dynamic studies.

In the following section model setup and numerical experiments are described, in which different atmospheric loads drive the sensitivity analysis. In the third section results are shown regarding validation against satellite data, chlorophyll at surface and in - vertical transects; then steady states of phosphorus and nitrogen in their organic and inorganic forms, subbasin biomasses, primary and secondary productions are introduced. Conclusions are outlined in the last section.

\section{Model setup}

\subsection{Hydrodynamics}

15 The EChoHYdrodynamical model of the Mediterranean Sea - ECHYM is MOM based and includes hydrostatic primitive equations in spherical coordinates with threedimensional grid spacing. Spatial resolution is $1 / 4$ degree in longitude and latitude, with 31 vertical levels centered at $5,15,30,50,70,90,120,160,200,240,280,320,360$, $400,440,480,520,580,660,775,925,1150,1450,1750,2050,2350,2650,2950$, $3250,3550,3850 \mathrm{~m}$ depth. Hydrodynamics is based on the 3-D primitive equations and takes into account the Boussinesq, the hydrostatic and the rigid-lid approximations:

$$
\frac{\partial v_{H}}{\partial t}+(\boldsymbol{v} \bullet \nabla) \boldsymbol{v}_{H}+\boldsymbol{f} \times \boldsymbol{v}_{H}=-\frac{1}{\rho_{0}} \nabla_{H}(p)-A_{H} \nabla_{H}^{4}\left(\boldsymbol{v}_{H}\right)+A_{V} \frac{\partial^{2} \boldsymbol{v}_{H}}{\partial z^{2}}
$$

$$
\frac{\partial p}{\partial z}=-\rho g
$$

\section{BGD}

4, 909-959, 2007

Mediterranean sensitivity to atmospheric inputs

M. Pacciaroni and G. Crispi

Title Page

Abstract

Conclusions

Tables

14

4

Back

Full Screen / Esc

Printer-friendly Version

Interactive Discussion 
$\frac{\partial \theta}{\partial t}+(\boldsymbol{v} \cdot \nabla) \theta=-K_{H}^{\theta} \nabla_{H}^{4}(\theta)+K_{V}^{\theta} \frac{\partial^{2} \theta}{\partial z^{2}}$

$\frac{\partial s}{\partial t}+(\boldsymbol{v} \bullet \nabla) s=-K_{H}^{s} \nabla_{H}^{4}(s)+K_{V}^{s} \frac{\partial^{2} s}{\partial z^{2}}$

$\rho=\rho(s, \theta, p)$

5 The velocity term $\boldsymbol{v}=(u, v, w)$ accounts for the three components in a spherical coordinate system $(\lambda, \varphi, z)$, while $v_{H}=(u, v)$ represents the horizontal velocity vector. The Coriolis term $\boldsymbol{f}$ is equal to $2 \Omega \sin \varphi \boldsymbol{k}$, with $\boldsymbol{k}$ vertical unitary vector, and $\rho, g, s, \theta, p$ are density, gravity acceleration, salinity, temperature, pressure, respectively.

The biharmonic $\nabla_{H}^{4}$ operator is employed both for momentum and tracer equa-

10 tions. Using this scheme, the biharmonic friction dumps, according with observations, more rapidly than second order Laplacian operator (Semtner and Mintz, 1977; Holland, 1978). $A_{H}=0.4 \times 10^{19} \mathrm{~cm}^{4} \mathrm{~s}^{-1}$ and $A_{V}=1.5 \mathrm{~cm}^{2} \mathrm{~s}^{-1}$ are the horizontal and vertical constant eddy viscosity coefficients. $K_{H}^{\theta}=K_{H}^{S}=0.2 \times 10^{19} \mathrm{~cm}^{4} \mathrm{~s}^{-1}$ and $K_{V}^{\theta}=K_{V}^{S}=0.3 \mathrm{~cm}^{2} \mathrm{~s}^{-1}$ are the horizontal and vertical constant turbulent diffusion coef15 ficients (Korres et al., 2000).

The ecomodel is driven by the National Center for Environmental Predictions (NCEP) monthly mean atmospheric analyses at 1000 mbar, covering the period 1980-1988.

The Gibraltar Strait and northern Adriatic, above $43^{\circ} \mathrm{N}$, are treated as buffer zones and consequently the thermohaline field is restored to the annual mean MED2 climatology; the imposed restoration time scale is 5 days.

The salinity is relaxed at the surface of the Mediterranean grid to the National Oceanographic Data Centre (NODC) monthly mean dataset. The relaxation time scale is 5 days and this represents the only constraint to the ecosystem dynamics.

The winter mixed layer, on average $150 \mathrm{~m}$, carries the surface tracers down to the thermocline depth; the model response in the summer season is triggered by these

Mediterranean sensitivity to atmospheric inputs

M. Pacciaroni and G. Crispi

Title Page

Abstract Introduction

Conclusions

Tables References Figures

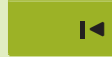

4

Back

Full Screen / Esc

Printer-friendly Version

Interactive Discussion

EGU 
mixing processes, with a summer mixed layer less than $10 \mathrm{~m}$ (Korres et al., 2000; see in particular Fig. 11). The absence of a structured, permanent thermocline is recognized as the main difference of the Mediterranean with respect to the ocean largescale circulation structure.

5 A schematic pattern of the Mediterranean general circulation can be described in terms of the four following basic constituents:

a) the presence of a non-returning flow of the low-salinity MAW from Gibraltar to the eastern end of the Levantine in the upper 150-200 m;

b) the formation and westward spreading of the warm and saline LIW at intermediate 10 depth (200-400 m) from the formation region in northwest Levantine and South Aegean Seas to the Gibraltar Strait, where it enters the Atlantic Ocean;

c) the formation of dense water mass in the Adriatic Sea and the subsequent southward and then eastward spreading, as it fills the deepest parts of the Eastern Mediterranean to form the Eastern Mediterranean Deep Water (EMDW);

15 d) the formation in the Gulf of Lions of the Western Mediterranean Deep Water (WMDW), which then spreads to the deep layers of the Western Mediterranean and participates to the Mediterranean outflow into Atlantic.

\subsection{Biotic compartments}

ECHYM biochemical interactions between producers, primary and secondary, and nutrients, inorganic and organic, are represented in Fig. 1.

The black arrows and strokes represent nitrogen flow, while the grey and the dark grey ones are respectively for phosphorus and for carbon. Fixed phosphorus:nitrogen:carbon ratios inside zooplankton and phytoplankton compartments are in effect. For detritus compartments they depend on the evolution of dynamics.

25 The evolution equation for the generic biochemical compartment $(B)$, which is resolved at the same grid of momentum equation, contains advection, diffusion, and local derivative terms to which vertical sinking and source term are added. Hence the

BGD

4, 909-959, 2007

Mediterranean sensitivity to atmospheric inputs

M. Pacciaroni and G. Crispi

Title Page

Abstract Introduction

Conclusions

Tables References Figures

14

4

Back

Full Screen / Esc

Printer-friendly Version

Interactive Discussion 
final equation takes this form:

$$
\frac{\partial(B)}{\partial t}+(\boldsymbol{v} \bullet \nabla)(B)=-K_{H}^{(B)} \nabla_{H}^{4}(B)+K_{V}^{(B)} \frac{\partial^{2}(B)}{\partial z^{2}}-w_{(B)} \frac{\partial(B)}{\partial z}+\left.\frac{\partial(B)}{\partial t}\right|_{\text {source }}
$$

BGD

4, 909-959, 2007

Biochemical tracers are all diffused with horizontal constant coefficient $K_{H}^{(B)}=0.2 \times$ $10^{19} \mathrm{~cm}^{4} \mathrm{~s}^{-1}$ and with a vertical one, $K_{V}^{(B)}$, equal to $1.5 \mathrm{~cm}^{2} \mathrm{~s}^{-1}$; the sinking ve5 locity, $w_{(B)}=5.0 \mathrm{~m} \mathrm{~d}^{-1}$, accounts for the detritus sedimentation; while the last term (i.e. $\left.\frac{\partial(B)}{\partial t}\right|_{\text {source }}$ ) represents all the loss/gain of the tracers at each grid point.

The water column instabilities, which arise from two adjacent levels, are resolved by mixing their contents for up to five subsequent iterations. On the other hand, phytoplankton and zooplankton instabilities are treated via borrowing: all biological sources 10 are set to zero and the calculation proceeds after appropriate excretion according to the specific ratios of phosphorus to carbon and nitrogen to carbon in the zooplankton.

The primary producers are based on two sizes of phytoplankton, describing the different behaviour of ultraplankton, size smaller than $10 \mu \mathrm{m}$ cells $(S)$, and netplankton, size larger than $10 \mu \mathrm{m}$ cells $(L)$. The smaller cells, described as a unique ultraplankton 15 compartments with mean parameters and processes, are mainly growing through regenerated production, while the larger cells, giving the netplankton compartment, are the producers of the major nutrient flux toward the intermediate layers of the sea. Their equations are respectively:

$\left.\frac{\partial S}{\partial t}\right|_{\text {source }}=\mu_{S} f(I) g_{S}(\theta) \frac{P}{P+k_{P S}} \times\left[\frac{N}{N+k_{N S}} e^{-\psi_{S} A}+\frac{A}{A+k_{A S}}\right] S-d_{S} S-k_{r S}^{*} S-k_{e S}^{*} S-\frac{S Z}{\alpha L+S+k_{H}}(8)$

$\left.20 \frac{\partial L}{\partial t}\right|_{\text {source }}=\mu_{L} f(I) g_{L}(\theta) \frac{P}{P+k_{P L}} \times\left[\frac{N}{N+k_{N L}} e^{-\psi_{L} A}+\frac{A}{A+k_{A L}}\right] L-d_{L} L-k_{r L}^{*} L-k_{e L}^{*} L-\frac{\alpha L Z}{\alpha L+S+k_{H}}$

in which $\mu_{S}$ and $\mu_{L}$ stand for the maximum growth rates, $f(I)$ represents the light limitation, $g_{S}(\theta)$ and $g_{L}(\theta)$ give the temperature dependencies.
Mediterranean

sensitivity to

atmospheric inputs

M. Pacciaroni and

G. Crispi

\section{Title Page}

Abstract

Introduction

Conclusions

Tables

References

Figures

14

4

Back
Printer-friendly Version

Interactive Discussion 
A full explanation of the biochemical parameters is given in Table 1. $k^{*}$ parameters represent $k$ parameters reported in Table 1 multiplied by the Arrhenius temperature dependent factor $\xi^{\theta-\theta_{0}}$.

The light limitation function $f(I)$ is calculated according to the following expression 5 (Steele, 1962):

$f(I)=r f \frac{l e^{-k_{z} z}}{l_{\mathrm{opt}}} e^{1-\frac{l^{-k_{z} z}}{l_{\text {opt }}}}$

in which $r f=\frac{\operatorname{arcos}(-\tan (d c) \tan (\varphi))}{\pi}$ is function of the sun declination $(d c)$ and latitude. $/$ is the incident radiation at the sea surface and depends on total incoming radiation $\left(I_{0}\right)$, cloud coverage ( $c l$, in tenths) and solar noon altitude ( $s b$, in degrees)

$10 \quad I=I_{0}(1-0.62 c I+0.0019 s b)$

$I_{\text {opt }}$ term stands for optimum adaptation radiation; $k_{z}\left(\mathrm{~cm}^{-1}\right)$ is the light extinction coefficient, which strongly varies from 0.00034 (far Eastern Mediterranean), 0.0005 (Ionian Sea), 0.0007 (Western Mediterranean), 0.00011 (Alboran Sea). These values are in accord with measures (Rabitti et al., 1994; Martin and Bart, 1995).

15 The nutrient limiting factor is represented by the product of the phosphorus Michaelis-Menten with the nitrogen expression, combining effects of ammonia and its inhibition on nitrate uptake. The $d_{S}$ and $d_{L}$ terms indicate loss of biomass due to lysis and mortality, $k_{r S}^{*}$ and $k_{r L}^{*}$ account for respiration, while $k_{e S}^{*}$ and $k_{e L}^{*}$ are exudation terms. The last term in Eq. (8) represents limitation by zooplankton ( $Z$ ) predation, in which $\alpha$ represents preference coefficient.

Temperature limitations both for small and large cells are introduced in $g_{S}(\theta)$ and $g_{L}(\theta)$ functions as follows (Lassiter and Kearns, 1974):

$g_{S}(\theta)=\left(\frac{\theta_{S \max }-\theta}{\theta_{S \max }-\theta_{S}}\right)^{b_{S}\left(\theta_{S \max }-\theta_{S}\right)} e^{b_{S}\left(\theta-\theta_{S}\right)}$

\section{BGD}

4, 909-959, 2007

Mediterranean sensitivity to atmospheric inputs

M. Pacciaroni and G. Crispi

Title Page

Abstract Introduction

Conclusions

Tables

References

Figures

14

4

Back

Close

Full Screen / Esc

Printer-friendly Version

Interactive Discussion 
$g_{L}(\theta)=\left(\frac{\theta_{L \max }-\theta}{\theta_{L \max }-\theta_{L}}\right)^{b_{L}\left(\theta_{L \max }-\theta_{L}\right)} e^{b_{L}\left(\theta-\theta_{L}\right)}$

BGD

Zooplankton is represented, according with type II functional response formulation (Holling, 1965), by the equation:

$$
\left.\frac{\partial Z}{\partial t}\right|_{\text {source }}=g \frac{R_{P C}}{r_{P C}} \frac{\varepsilon_{S} S+\alpha \varepsilon_{L} L}{S+\alpha L+k_{H}} Z-d_{Z} Z-k_{e x Z}^{*} Z
$$

5 The zooplankton grazes through a rectangular hyperbolic expression, using herbivores typical values for the grazing rate and half-saturation (Fasham et al., 1990). In ECHYM the zooplankton composition is fixed at different $\mathrm{P}: \mathrm{N}: \mathrm{C}$ ratio $(1: 12: 48)$ with respect to phytoplankton one $(1: 16: 106)$, in line with the stoichiometry of the herbivorous taxonomy (Beers, 1966). The specific mortality does not depend on physical parameters and is chosen as a typical temperate area average (Davis, 1987), while the excretion is in agreement with the relation given in Wen and Peters (1994), particularly the temperature dependence of excretion doubles the value every $10^{\circ} \mathrm{C}$ (McLaren, 1965). The efficiency parameters focus the prevalent carbon flux path from the phytoplanktonic groups to zooplankton. In fact, the efficiency from the ultraplankton to the herbivores is smaller than that from the netplankton, respectively $\varepsilon_{S}$ and $\varepsilon_{L}$ in Table 1 , in line with increasing nitrogen with respect to phosphorus release rates at the decreasing daily excretion.

\subsection{Nutrients}

The dissolved inorganic phosphorus is given by Eq. (15), in which respiration and exudation from phytoplankton, excretion from zooplankton, and phosphate remineralization, are positive terms, while the uptakes toward primary producers represent negative

\section{Mediterranean sensitivity to atmospheric inputs}

M. Pacciaroni and G. Crispi

Title Page

Abstract Introduction

Conclusions

Tables References Figures

14

4

Back

Close

Full Screen / Esc

Printer-friendly Version

Interactive Discussion 
ones:

$$
\begin{aligned}
&\left.\frac{\partial P}{\partial t}\right|_{\text {source }}=R_{P C} k_{r S}^{*} S+R_{P C} k_{r L}^{*} L+R_{P C} k_{e S}^{*} S+R_{P C} k_{e L}^{*} L+r_{P C} k_{e x Z}^{*} Z+k_{d e C P}^{*} D_{P}- \\
& R_{P C} \mu_{S} f(I) g_{S}(\theta) \frac{P}{P+k_{P S}} \times \\
& \times\left[\frac{N}{N+k_{N S}} e^{-\psi_{S} A}+\frac{A}{A+k_{A S}}\right] S-R_{P C} \mu_{L} f(I) g_{L}(\theta) \frac{P}{P+k_{P L}} \times\left[\frac{N}{N+k_{N L}} e^{-\psi_{L} A}+\frac{A}{A+k_{A L}}\right] L
\end{aligned}
$$

\section{BGD}

4, 909-959, 2007

Nitrates increase according to nitrification of ammonia in presence of oxygen and decrease for phytoplankton uptakes:

$$
\begin{aligned}
& \left.\frac{\partial N}{\partial t}\right|_{\text {source }}=k_{n i t}^{*} \frac{O}{O+k_{A O}} A-R_{N C} \mu_{S} f(I) g_{S}(\theta) \times \frac{P}{P+k_{P S}} \frac{N}{N+k_{N S}} e^{-\psi_{S} A} S- \\
& -R_{N C} \mu_{L} f(I) g_{L}(\theta) \frac{P}{P+k_{P L}} \times \frac{N}{N+k_{N L}} e^{-\psi_{L} A} L
\end{aligned}
$$

In Eq. (17) ammonia compartment is parameterized similarly to phosphate, considering as extra terms the loss due to ammonia nitrification and the enhanced excretion term via sloppy feeding:

$$
\begin{aligned}
& \left.\frac{\partial A}{\partial t}\right|_{\text {source }}=R_{N C} k_{r S}^{*} S+R_{N C} k_{r L}^{*} L+R_{N C} k_{e S}^{*} S+R_{N C} k_{e L}^{*} L+r_{N C} k_{\mathrm{exz}}^{*} Z+k_{\mathrm{dec} N}^{*} D_{N}+ \\
& +R_{N C} g\left(1-\frac{R_{P C} r_{N C}}{R_{N C} r_{P C}}\right) \times \frac{\varepsilon_{S} S+\alpha \varepsilon_{L} L}{S+\alpha L+k_{H}} Z-k_{\mathrm{nit}}^{*} \frac{O}{O+k_{A O}} A-R_{N C} \mu_{S} f(I) g_{S}(\theta) \frac{P}{P+k_{P S}} \frac{A}{A+k_{A S}} S- \\
& -R_{N C} \mu_{L} f(I) g_{L}(\theta) \frac{P}{P+k_{P L}} \frac{A}{A+k_{A L}} L
\end{aligned}
$$

\subsection{Detritus}

The detritus is divided into its phosphorus, nitrogen and carbon contents, see Eqs. (18), (19) and (20). All remineralization processes are included, involving non-living organic matter behaviour outside the euphotic zone.

$$
\begin{aligned}
& \left.\frac{\partial D_{P}}{\partial t}\right|_{\text {source }}=r_{P C} d_{Z} Z+R_{P C} d_{S} S+R_{P C} d_{L} L+ \\
15+ & +R_{P C}\left[\left(1-\varepsilon_{S}\right) \frac{g S Z}{S+\alpha L+k_{H}}+\left(1-\varepsilon_{L}\right) \frac{g \alpha L Z}{S+\alpha L+k_{H}}\right]-k_{\text {dec } P}^{*} D_{P} \\
& 919
\end{aligned}
$$

Mediterranean

sensitivity to

\section{atmospheric inputs}

M. Pacciaroni and

G. Crispi

\section{Title Page}

Abstract

Introduction

Conclusions

Tables

References

Figures

14

4

Back

Close
Printer-friendly Version

Interactive Discussion

EGU 


$$
\begin{aligned}
& \left.\frac{\partial D_{N}}{\partial t}\right|_{\text {source }}=r_{N C} d_{Z} Z+R_{N C} d_{S} S+R_{N C} d_{L} L+ \\
& +R_{N C}\left[\left(1-\varepsilon_{S}\right) \frac{g S Z}{S+\alpha L+k_{H}}+\left(1-\varepsilon_{L}\right) \frac{\alpha g L Z}{S+\alpha L+k_{H}}\right]-k_{\text {dec } N}^{*} D_{N} \\
& \left.\frac{\partial D_{C}}{\partial t}\right|_{\text {source }}=d_{Z} Z+d_{S} S+d_{L} L+\left[\left(1-\varepsilon_{S}\right) \frac{g S Z}{S+\alpha L+k_{H}}+\left(1-\varepsilon_{L}\right) \frac{\alpha g L Z}{S+\alpha L+k_{H}}\right]- \\
& -k_{\text {dec } C}^{*} D_{C}
\end{aligned}
$$

The expression in square brackets of Eqs. (18), (19) and (20) represents the not5 assimilated carbon rate, both from ultraplankton and netplankton, generated during grazing activity.

\subsection{Oxygen}

The surficial oxygen $(\mathrm{O})$ relaxation is performed by using the reaeration process, as function of temperature and salinity (Gromiec, 1983):

$$
\begin{aligned}
& \left.\frac{\partial O}{\partial t}\right|_{\text {source }}=R_{O C} \mu_{S} f(I) g_{S}(\theta) \frac{P}{P+k_{P S}}\left[\frac{N}{N+k_{N S}} e^{-\psi_{S} A}+\frac{A}{A+k_{A S}}\right] S+R_{O C} \mu_{L} f(I) g_{L}(\theta) \frac{P}{P+k_{P L}} \times \\
& \times\left[\frac{N}{N+k_{N L}} e^{-\psi_{L} A}+\frac{A}{A+k_{A L}}\right] L-R_{O C} k_{r S}^{*} S-R_{O C} k_{r L}^{*} L-R_{\text {nit }} k_{\text {nit }}^{*} \frac{O}{O+k_{A O}} A-R_{O C} k_{\text {dec }}^{*} D_{C}+\text { rel }
\end{aligned}
$$

in which $\mathrm{rel}_{O}$ is given by:

$$
\operatorname{rel}_{O}=k_{\text {aer }}\left(\left(457.01-11.47 \theta+0.14 \theta^{2}-3.02 s+0.064 \theta s+0.0086 s^{2}\right)-0\right)
$$

\subsection{Initial conditions}

Initialization profiles for nitrates and phosphates are derived from MEDAR/MEDATLAS

II dataset (MEDAR Group, 2002), interpolated at each point of the grid (Crise et

\section{BGD}

4, 909-959, 2007

Mediterranean sensitivity to atmospheric inputs

M. Pacciaroni and
G. Crispi

\section{Title Page}

Abstract

Conclusions

Tables

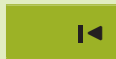

4

Back

Full Screen / Esc

Printer-friendly Version 
al., 2003). At the beginning of the spin-up, oxygen is set to $250 \mu \mathrm{molO} \mathrm{dm}^{-3}$; netplankton and ultraplankton are initialized to $0.1 \mu \mathrm{mol} \mathrm{C} \mathrm{dm}^{-3}$, while zooplankton to $0.01 \mu \mathrm{mol} \mathrm{C} \mathrm{dm}^{-3}$. Detritus and ammonia compartments are set to zero initial values.

A test case has been performed in order to appreciate the conservation of total ni5 trate and phosphate in the basin, thought as a closed system (Pacciaroni and Crispi, 2003). The maximal error, during two years of model simulation, on the total content is estimated in 70 ton for nitrogen and 1.6 ton for phosphorus all over the basin. Consequently, the model works appropriately in terms of nitrogen and phosphorus yearly budgets with an uncertainty less than $0.01 \%$ for both nutrient fluxes.

10 Restoration of all biochemical parameters to the initial conditions is in effect in the Adriatic Sea buffer zone, more northerly than $43^{\circ} \mathrm{N}$. The biochemical variables in the Aegean Sea buffer zone, more northerly than $38^{\circ} \mathrm{N}$, are restored to the prescribed initial values. These choices help in describing the climatological effects due respectively to the Po River inputs and the Bosphorus exchanges, with the same $\alpha_{B}$ restoration 5 time.

Two rivers are introduced, the Rhone River in the western basin and the Nile River in the eastern one. The first one gives about $3.18 \times 10^{-6} \mu \mathrm{molN} \mathrm{dm}^{-3} \mathrm{~s}^{-1}$ and $9.31 \times 10^{-8} \mu \mathrm{molP} \mathrm{dm}{ }^{-3} \mathrm{~s}^{-1}$ (Durrieu de Madron et al., 2001), while the second contributes with $6.82 \times 10^{-7} \mu \mathrm{mol} \mathrm{Ndm}{ }^{-3} \mathrm{~s}^{-1}$ and $8.24 \times 10^{-8} \mu \mathrm{mol} \mathrm{Pdm}^{-3} \mathrm{~s}^{-1}$ (Hamza, 2001).

Three runs are selected to estimate the answer of the basin system with respect to different atmospheric inputs of dissolved inorganic nitrogen (DIN) and phosphorus (DIP), but with the same physics driving these three different ecosystem scenarios. In the first one, atmospheric deposition is not taken into account and it is defined as the no 25 inputs run (NIRUN). The second one represents the "Continuous inputs after Guerzoni et al. (1999; see Table 16 of their work)", referred hereafter as GARUN.

The third one follows another, intermediate load of nutrients, the "Continuous inputs after Ribera et al. (2003; see Table 7)", indicated as AVRUN. The constant atmospheric inputs, see Tables 2 and 3, are loaded at the first vertical level (10 $\mathrm{m}$ depth) and for each
BGD

4, 909-959, 2007

Mediterranean sensitivity to atmospheric inputs

M. Pacciaroni and G. Crispi

Title Page

Abstract Introduction

Conclusions

Tables References Figures

14

4

Back

Full Screen / Esc

Printer-friendly Version

Interactive Discussion 
time step in the global Mediterranean grid, taking into account three different loads in the eastern (Markaki et al., 2003; from Table 3, the inputs comes from dry and wet sum), central and western basin (Bergametti et al., 1992, Loÿe-Pilot et al., 1990). The central area GARUN inputs in Tables 2 and 3 are directly estimated from the authors, 5 Wh

while AVRUN ones are the eastern and western mean values.

Surface chlorophyll estimations are achieved by applying the statistical expression as obtained by Cloern et al. (1995) for diatom cultures, and extending it to small cells:

$$
\begin{aligned}
& \frac{\mathrm{Chl}_{L}}{L}=0.003+0.0154 \times \exp ^{[0.05 \times \theta]} \times \exp \left[-0.059 \frac{{ }^{10\left(1-\exp \left[-K_{z} \times z_{0}\right]\right)}}{K_{z} \times z_{0}}\right] \times \frac{P}{P+k_{P L}} \times \\
& {\left[\frac{N}{N+k_{N L}} \times \exp ^{\left[-\psi_{L} A\right]}+\frac{A}{A+k_{A L}}\right]}
\end{aligned}
$$$$
\frac{\mathrm{Ch}_{S}}{S}=0.003+0.0154 \times \exp ^{[0.05 \times \theta]} \times \exp \left[-0.059 \frac{10\left(1-\exp \left[-k_{z} \times z_{0}\right]\right)}{k_{z} \times z_{0}}\right] \times \frac{P}{P+k_{P S}} \times
$$$$
\left[\frac{N}{N+k_{N S}} \times \exp ^{\left[-\psi_{S} A\right]}+\frac{A}{A+k_{A S}}\right] R_{S L}
$$

10 In Eqs. (23) and (24) $\mathrm{Chl}_{L}$ and $\mathrm{Chl}_{S}$ are the chlorophyll concentrations $\left(\mathrm{mg} \mathrm{Chl} \mathrm{m}^{-3}\right.$ ) for large and small cells respectively, $\theta$ is the potential temperature $\left({ }^{\circ} \mathrm{C}\right), I_{0}$ stands for surficial irradiance (mol quanta $\mathrm{m}^{-2} \mathrm{~d}^{-1}$ ), $k_{z}$ is the light extinction coefficient $\left(\mathrm{cm}^{-1}\right.$ ) and $z_{0}$ is the upper layer depth $(\mathrm{cm})$. These evaluations are obtained on the basis of laboratory experiments performed in different nutrient and light conditions.

The Chl:C ratio is estimated in the sub-surficial layers on the basis of experimental in situ data. For the northwestern Mediterranean, Jacques et al. (1973) give integrated values of about $67.0 \mathrm{mg} \mathrm{Chl} \mathrm{m}^{-2}$ in the upper layer of $200 \mathrm{~m}$; while Nival et al. (1975) for the same cruise give $3.83 \mathrm{~g} \mathrm{C} \mathrm{m}^{-2}$ for the phytoplankton biomass in the same layer. This gives on average a value of $\mathrm{Chl}: \mathrm{C}$ around 0.0175. For the Eastern Mediterranean, the estimation of this ratio is more difficult due to the sparseness of data. Estimations are present in the Aegean Sea where values of about $18.8 \mathrm{mg} \mathrm{Chl} \mathrm{m}^{-2}$ are given for
BGD

4, 909-959, 2007

Mediterranean sensitivity to atmospheric inputs

M. Pacciaroni and G. Crispi

Title Page

Abstract Introduction

Conclusions

Tables References Figures

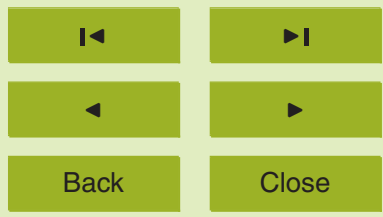

Full Screen / Esc

Printer-friendly Version

Interactive Discussion

EGU 
1.5 of the critical depth (Vidussi et al., 2001). On the other hand, in the same season Siokou-Frangou et al. (2002) give $1.89 \mathrm{~g} \mathrm{C} \mathrm{m}^{-2}$ in the upper $100 \mathrm{~m}$. Referring the estimations to the same layer, the ratio found is equivalent on average to 0.0073 . The chosen ratios for the transformations in depth follow in Table 4.

\section{$5 \quad 3$ Results}

\subsection{Model validation using CZCS data}

Validation of the model is performed using the chlorophyll monthly concentration maps in the pelagic Mediterranean Sea estimated by the Coastal Zone Color Scanner installed on board of the satellite Nimbus-7 from 1979 to 1985 (Feldman et al., 1994).

10 These CZCS concentrations taken in the same period of the model's forcing function, are the calibrated elaborations of those maps, as produced at ISPRA EC Joint Research Centre (Sturm et al., 1999).

Concerning the model counterpart, surficial chlorophyll at each horizontal grid point is calculated as follows. Values at 5 and $15 \mathrm{~m}$ depth are employed in order to obtain $1510 \mathrm{~m}$ average surface phytoplankton biomass and nutrient concentrations. The Cloern et al. (1995) expressions, Eqs. (23) and (24), need as well temperature, surficial irradiance, the same for each year, and light extinction coefficient, which characterize each point in the horizontal grid. Each monthly-modelled upper layer chlorophyll is the average of the three corresponding months of the last three simulated years.

In Figs. 2a, b monthly averaged surface chlorophyll concentrations are shown for the western and eastern basin by excluding the coastal areas, i.e. shallower than $200 \mathrm{~m}$.

On yearly average, NIRUN chlorophyll excess is about $5 \%$ with respect to CZCS data in the Western Mediterranean, while in the Eastern Mediterranean the results appear about $25 \%$ lower than CZCS ones. Satellite and ECHYM chlorophyll concentrations show the highest values during early winter (December-January) in the western basin, while they tend to decrease in summer. In the Eastern Mediterranean maxima are

\section{BGD}

4, 909-959, 2007

Mediterranean sensitivity to atmospheric inputs

M. Pacciaroni and G. Crispi

Title Page

Abstract Introduction

Conclusions

Tables References Figures

14

4

Back

Full Screen / Esc

Printer-friendly Version

Interactive Discussion 
detected in February and minima during summer. The correlation between measured and simulated data, quite good in the Western Mediterranean, with a value of 0.86 , remains good also in the eastern basin (0.76).

\subsection{Yearly averaged surface chlorophyll}

5 In Fig. 3a the calculated yearly averaged Chl:C ratio is shown for the GARAN ultraplankton in the whole Mediterranean basin. The western side of the Mediterranean Sea shows the greatest values, 0.018, in the Gulf of Lions and in the south of Sardinia. The lower Chl: $\mathrm{C}$ ratio is detected in the extreme eastern basin with about 0.008 . In Fig. $3 b$ the Chl:C ratio is contoured for GARAN netplankton, giving values about halved than those in Fig. 3a.

The annual modelled upper layer chlorophyll averages are shown in Figs. 4a and $4 b$ - respectively NIRUN and GARUN - for areas deeper than $200 \mathrm{~m}$. AVRUN results (not shown) are very similar to GARUN ones. In Fig. 4a the Alboran basin is clearly affected by high chlorophyll with respect to the whole basin, values reach about $150.8 \mathrm{mg} \mathrm{Chl} \mathrm{m}^{-3}$. In the northwestern basin, especially in the Ligurian one, values are $0.35-0.40 \mathrm{mg} \mathrm{Chl} \mathrm{m}^{-3}$, while in the central and in the less oligotrophic parts of the eastern basin the contributions are in the range $0.1-0.2 \mathrm{mg} \mathrm{Chl} \mathrm{m}^{-3}$. In the south and central Ionian and in the far Eastern Mediterranean, values are well below $0.05 \mathrm{mg} \mathrm{Chl} \mathrm{m}^{-3}$.

The Alboran Sea and the Balearic basin show also in the GARUN simulation (Fig. 4b) 20 very high values, the greatest in the Mediterranean Sea. Comparing Figs. $4 \mathrm{a}$ and $4 \mathrm{~b}$ no main influence is detected, in those specific areas, in response to the atmospheric loads. Looking at the DIN and DIP contributions allow the development of well defined structures in the Tyrrhenian Sea and in the south of Sardinia basin, evidenced by chlorophyll signals of different intensity. Particularly the structures evidenced in Fig. 4a

in the south of Sardinia, and west and south of Sicily are reinforced when looking at Fig. 4b. The near-surface chlorophyll signal in the Tyrrhenian Sea, affected by the cyclonic circulation in this region, is nutrient-enriched also because of the northwest Sicilian maxima of $0.5 \mathrm{mg} \mathrm{Chl} \mathrm{m}^{-3}$. The Eastern Mediterranean chlorophyll signal is

BGD

4, 909-959, 2007

Mediterranean sensitivity to atmospheric inputs

M. Pacciaroni and G. Crispi

Title Page

Abstract Introduction

Conclusions

Tables References Figures

14

4

Back

Full Screen / Esc

Printer-friendly Version

Interactive Discussion

EGU 
homogenously increased when compared with Fig. $4 \mathrm{a}$, reaching $0.2 \mathrm{mg} \mathrm{Chl} \mathrm{m}^{-3}$ in the GARUN.

In Fig. 4c the stations, which contribute to the MEDAR/MEDATLAS II dataset, are displayed. Yearly averaged data are considered because of their time-scattered sam5 pling distribution. It is evident that many coastal zones of southern Mediterranean as well as Tyrrhenian Sea, north Libya and Egypt coast are not covered at all. Gridded biomass fields have been computed using the Variational Inverse Model (VIM). The fields approximate the data and exhibit small spatial variations. The target of the analysis is the smoothest field that respects the consistency with the observed values. The 10 analysis is obtained as the minimum of a variational principle in a horizontal space (Rixen et al., 2001).

The chlorophyll VIM climatology, sampled in the starred stations plotted in Fig. 4c, is represented in Fig. 4d (MEDAR Group, 2002). Chosen layer depth is $10 \mathrm{~m}$ in analogy with ECHYM results, and also the color scale is the same. There is clear east-west 15 increasing gradient across the whole basin, from values less than $0.06 \mathrm{mg} \mathrm{Chl} \mathrm{m}^{-3}$ in the far Levantine Sea to concentrations higher than $0.7 \mathrm{mg} \mathrm{Chl} \mathrm{m}^{-3}$ in the Alboran Sea; the south-north gradient reaches the highest values in the Aegean Sea 0.08$0.30 \mathrm{mg} \mathrm{Chl} \mathrm{m}^{-3}$, in the Adriatic Sea $0.23-0.35 \mathrm{mg} \mathrm{Chl} \mathrm{m}^{-3}$, and in the Gulf of Lions $0.43-0.60 \mathrm{mg} \mathrm{Chl} \mathrm{m}^{-3}$. NIRUN and GARUN results are in keeping, lower the former 20 and higher the latter, with experimental data considering Ionian Sea, Levantine basin and south Adriatic and Aegean Seas. In the Alboran Sea, Balearic Basin and Gulf of Lions, NIRUN results show good agreement with respect to VIM estimations, qualitatively and quantitatively. It is worth pointing out the smoothing in Fig. $4 \mathrm{~d}$ of the enriched signatures, due to upwelling and gyres, more evident in ECHYM results (Figs. 4a and 25 b).

Figure 5 shows the annual mean chlorophyll anomalies: at each grid point, NIRUN surficial chlorophyll concentrations is subtracted from GARUN ones.

The influence of the atmospheric inputs is more evident along the north Tyrrhenian coast, where, as seen in Fig. 4b, very high chlorophyll values are detected. The Lev-

BGD

4, 909-959, 2007

Mediterranean sensitivity to atmospheric inputs

M. Pacciaroni and G. Crispi

Title Page

Abstract Introduction

Conclusions

Tables

References

Figures

14

4

Back

Full Screen / Esc

Printer-friendly Version

Interactive Discussion 
antine basin, southern Ionian and Tyrrhenian Sea show a clearly positive anomaly of $0.05 \mathrm{mg} \mathrm{Chl} \mathrm{m}^{-3}$; also the central lonian and the Balearic basin present a slightly positive value of $0.02 \mathrm{mg} \mathrm{Chl} \mathrm{m}^{-3}$; otherwise negative values are detected mainly in the Alboran Sea and Gulf of Lions with little change in the central Adriatic Sea. These neg-

5 ative effects are evidenced by a more developed total biomass in the NIRUN simulation for these restricted areas, when an annual time scale is considered, due respectively to the anticyclonic circulation and to the cyclonic gyre boundary affected by topographic effects.

Western and Eastern Mediterranean surface chlorophyll estimations for the three dif10 ferent runs are summarized in Table 5, excluding coastal areas. NIRUN concentrations are lower than those fertilized by the atmospheric loads, which are very close in value between them. Considering the former run, the ratio of the chlorophyll concentration in the western basin is three times that in the eastern one, while it is twice in GARUN and AVRUN.

15 Surficial VIM chlorophyll data are well below the atmospheric runs results, but they are also clearly lower than the NIRUN averaged concentrations.

Also the satellite estimations obtained from CZCS dataset are reported. They result higher than VIM climatology estimations, giving values very close to NIRUN.

\subsection{Vertical chlorophyll distributions}

20 Two vertical transects, reproducing the annual mean chlorophyll distributions in depth, are studied in this work. The first zonal transect at $34^{\circ} \mathrm{N}$ (Fig. 6) shows the sub-surficial, i.e. from surface to $200 \mathrm{~m}$ depth, chlorophyll concentration. It is representative for this eastern basin southern area. The second meridional one at $6^{\circ} \mathrm{E}$ (Fig. 8) shows the vertical structure between Algerian and south French coast.

25 In Figs. 6a, b and c ECHYM estimations are shown and they are characterized by a deep chlorophyll maximum (DCM) at about $100 \mathrm{~m}$ in the central and eastern side of the vertical transect while in the western side it appears shallower, at about $40 \mathrm{~m}$. In the center of the transect of Fig. $6 \mathrm{a}$, a DCM of $0.25 \mathrm{mg} \mathrm{Chl} \mathrm{m}^{-3}$ is recognized,

\section{BGD}

4, 909-959, 2007

Mediterranean sensitivity to atmospheric inputs

M. Pacciaroni and G. Crispi

Title Page

Abstract Introduction

Conclusions

Tables References Figures

14

4

Back

Full Screen / Esc

Printer-friendly Version

Interactive Discussion

EGU 
while it decreases to $0.20 \mathrm{mg} \mathrm{Chl} \mathrm{m}^{-3}$ moving westward. The remaining region shows lower chlorophyll signatures of about $0.15 \mathrm{mg} \mathrm{Chl} \mathrm{m}^{-3}$ or less. The chlorophyll signal is more pronounced from surface down to $100 \mathrm{~m}$ in the GARUN simulation, see Fig. $6 \mathrm{~b}$. Here the lowest concentration is $0.15 \mathrm{mg} \mathrm{Chl} \mathrm{m}^{-3}$ near surface and then increases to $50.20 \mathrm{mg} \mathrm{Chl} \mathrm{m}^{-3}$ excluding the DCM in which it reaches $0.25-0.30 \mathrm{mg} \mathrm{Chl} \mathrm{m}^{-3}$. An even higher chlorophyll level is detected at surface in Fig. 6c, in the AVRUN simulation. Although the signal is very close in value to that of Fig. 6b, it involves a wider area toward surface. The extension in depth of the chlorophyll signals appears the same for each transect in Figs. 6a, b and c.

10 In Fig. 6d annual mean chlorophyll contribution coming from VIM climatology is reported. It is worth noting the agreement with ECHYM results in the eastern side of the vertical transects where a DCM of about $0.20 \mathrm{mg} \mathrm{Chl} \mathrm{m}^{-3}$ is shown at $100 \mathrm{~m}$. Likewise, in the surficial level at about $35^{\circ} \mathrm{E}$ in Fig. $6 \mathrm{~d}$, a more intense chlorophyll signal of $0.15 \mathrm{mg} \mathrm{Chl} \mathrm{m}^{-3}$ is detected with respect to the surroundings. The presence of river inputs in the Israeli coastal area (see Fig. 6d) shows good accordance with the ecomodel, particularly with GARUN and AVRUN (Figs. 6b and c). In the western side of Fig. $6 \mathrm{~d}$ chlorophyll values reach about $0.30 \mathrm{mg} \mathrm{Chl} \mathrm{m}^{-3}$ in the DCM, while they attain $0.25 \mathrm{mg} \mathrm{Chl} \mathrm{m}^{-3}$ maxima in Figs. $6 \mathrm{a}, \mathrm{b}$ and c; however DCM in the data is deeper, about $80 \mathrm{~m}$, with respect to $50 \mathrm{~m}$ in ECHYM. Anyway this area from $10^{\circ} \mathrm{E}$ to $15^{\circ} \mathrm{E}$ is poorly 20 covered by experimental profiles (Fig. 4c), indicating extrapolation approximations in the reconstructed field.

In order to consider biomass content in the euphotic zone, integrated $(0-200 \mathrm{~m})$ chlorophyll values along the zonal vertical transect of Fig. 6 are shown in Fig. 7 . In the western side of the vertical transect, data reach higher values, about $25 \mathrm{mg} \mathrm{Chl} \mathrm{m}^{-2}$, 25 while ECHYM runs remain to lower values around $13 \mathrm{mg} \mathrm{Chl} \mathrm{m}^{-2}$. In the eastern side of the zonal transect, GARUN and AVRUN display very similar integrated quantities. NIRUN results are close to vertical integrated line from data, showing in this side mean values of $20 \mathrm{mg} \mathrm{Chl} \mathrm{m}^{-2}$. Anyway both are lower than the atmospheric runs, around $27 \mathrm{mg} \mathrm{Chl} \mathrm{m}^{-2}$, because of possible overestimation of the atmospheric loads. Averages
BGD

4, 909-959, 2007

Mediterranean sensitivity to atmospheric inputs

M. Pacciaroni and G. Crispi

Title Page

Abstract Introduction

Conclusions

Tables

References

Figures

14

4

Back

Full Screen / Esc

Printer-friendly Version

Interactive Discussion 
along the entire transect are reported in the legend of Fig. 7 for each model simulation and for VIM climatology. ECHYM results, particularly considering atmospheric input cases, are very close to VIM ones and to the above-cited value, $18.8 \mathrm{mg} \mathrm{Chl} \mathrm{m}^{-2}$, by Vidussi et al. (2001).

5 In the western vertical meridional transect a more evident and shallower DCM appears at about $30 \mathrm{~m}$ depth in Figs. $8 \mathrm{a}, \mathrm{b}$ and $\mathrm{c}$, than in the above-discussed eastern zonal one (Figs. $6 \mathrm{a}, \mathrm{b}$ and $\mathrm{C}$ ). In Fig. $8 \mathrm{a}$ around $40^{\circ} \mathrm{N}$ and about $30 \mathrm{~m}$ depth, $\mathrm{DCM}$ reaches maxima of $0.60 \mathrm{mg} \mathrm{Chl} \mathrm{m}^{-3}$, while on the same depth, but northernmore, it is about $0.50 \mathrm{mg} \mathrm{Chl} \mathrm{m}^{-3}$. In GARUN result of Fig. 8b, the DCM is higher in 10 the central zone of the meridional transect $\left(0.65 \mathrm{mg} \mathrm{Chl} \mathrm{m}^{-3}\right)$ and in the northern side $\left(0.55 \mathrm{mg} \mathrm{Chl} \mathrm{m}^{-3}\right)$. It is also worth noting the presence of a chlorophyll signal in the north coast of Algeria with values of about $0.35 \mathrm{mg} \mathrm{Chl} \mathrm{m}^{-3}$. The model result in Fig. $8 \mathrm{c}$ (AVRUN) is very close in value and maxima position with that of Fig. 8b (GARUN); the presence of a DCM at surface in Fig. $8 \mathrm{a}$ is more evident in Figs. $8 \mathrm{~b}$ and c, with values 5 higher than $0.60 \mathrm{mg} \mathrm{Chl} \mathrm{m}^{-3}$, signal of the cyclonic gyre effects.

The VIM climatology is represented in Fig. 8d where a DCM is located at about $80 \mathrm{~m}$ in the centre of the transect with concentration of about $0.50 \mathrm{mg} \mathrm{Chl} \mathrm{m}^{-3}$. In the northern side of the vertical transect this maximum is confirmed, although at shallower depth (about $30 \mathrm{~m}$ ).

20 It is worth pointing out the agreement between data (Fig. 8d) and ECHYM estimations, for what concerns the surficial and sub-surficial chlorophyll maximum revealed in the north side of the transect, prevalently in the GARUN and AVRUN cases (Figs. 8b and $\mathrm{c}$ ). The annual vertical chlorophyll variability modelled by ECHYM matches data (Fig. 8d) with some overestimation for the GARUN and AVRUN, particularly in the central areas of the section (Figs. 8b and c). Furthermore in this zone the DCM appears shallower than experimental data. This disagreement depends on the lack of seasonality in the VIM climatology, being Fig. 8d a summer representation (besides with a large variability from 50 to $80 \mathrm{~m}$ depth, courtesy $\mathrm{M}$. Burca). This point remains open to a more extensive experimental monitoring (coverage in time) and to a more resolved
BGD

4, 909-959, 2007

Mediterranean sensitivity to atmospheric inputs

M. Pacciaroni and G. Crispi

Title Page

Abstract Introduction

Conclusions

Tables

References

Figures

14

- I

4

Back

Close

Full Screen / Esc

Printer-friendly Version

Interactive Discussion 
eddy-permitting modelling (small anticyclonic structures).

Integrated $(0-200 \mathrm{~m})$ chlorophyll values along the meridional vertical transect of Fig. 8 are now considered in Fig. 9. VIM climatology is smooth and constant, about $36 \mathrm{mg} \mathrm{Chl} \mathrm{m}^{-2}$, along the transect; among other things, the high productivity area of 5 the northwestern Mediterranean is not well represented. ECHYM runs, on the other hand, show a similar trend, conserving a strong spatial variability, with a south-north increasing gradient from $20 \mathrm{mg} \mathrm{Chl} \mathrm{m}^{-2}$ in the north coast of Algeria to $55 \mathrm{mg} \mathrm{Chl} \mathrm{m}^{-2}$ in the south coast of France. In this last region high-integrated chlorophyll values of about $67 \mathrm{mg} \mathrm{Chl} \mathrm{m}^{-2}$ were found (Jacques et al., 1973). Averaged values of the en10 tire meridional transect are summarized in the legend of Fig. 9. ECHYM results range around $31-32 \mathrm{mg} \mathrm{Chl} \mathrm{m}^{-2}$, and they are just below the experimental average of the VIM climatology, $36 \mathrm{mg} \mathrm{Chl} \mathrm{m}^{-2}$.

\subsection{Upper layer nitrogen and phosphorus at steady state}

The relative amounts of nitrogen and phosphorus, in the western and eastern photic 15 basin, are respectively reported in Figs. 10 and 11.

The total nitrogen amounts, divided among the biochemical compartments in the eastern basin, show that ultraplankton increases from $8.6 \%$ to $10.2 \%-10.5 \%$ of the total content, when NIRUN (Fig. 10a) is compared to GARUN (Fig. 10b) and AVRUN (Fig. 10c). On the contrary, netplankton decreases from $4.0 \%$ to $3.5 \%-3.3 \%$ of the 20 total nitrogen in the photic layer. Zooplankton instead can be considered not greatly affected by the inputs. Moreover the ultraplankton takes the larger biomass among them, with respect to the total mass.

In the western basin (Figs. 10d, e and f), both biotic and abiotic contents approximately conserve their fractions of the total content; nevertheless netplankton in NIRUN reveals the higher content (4.0\%) compared to GARUN and AVRUN.

Eastern and western nitrogen total contents, frames below the pie diagrams, follow the DIN inputs of Table 2: they reach for the Eastern Mediterranean the maximum value in the case of AVRUN $\left(217.9 \mathrm{mmol} \mathrm{N} \mathrm{m}^{-2}\right)$, for the Western Mediterranean in GARUN

BGD

4, 909-959, 2007

Mediterranean sensitivity to atmospheric inputs

M. Pacciaroni and G. Crispi

Title Page

Abstract Introduction

Conclusions

Tables

References

Figures

14

4

Back

Full Screen / Esc

Printer-friendly Version

Interactive Discussion

EGU 
$\left(212.5 \mathrm{mmol} \mathrm{N} \mathrm{m}^{-2}\right)$.

The phosphorus repartition in the biological compartments is represented in Fig. 11, BGD where ultraplankton clearly dominates the Eastern Mediterranean and increases with the atmospheric deposition showing in the NIRUN, GARUN and AVRUN the corre5 sponding scores: $6.5 \%, 8.8 \%, 10.2 \%$. Netplankton is poorly affected by the inputs (from $3.0 \%$ to $3.2 \%$ ).

In the western basin (Figs. 11d, e and f) the ultraplankton slightly increases in the atmospheric input runs, netplankton can be assumed unaffected, while zooplankton has higher values (4.2\%) in GARUN and AVRUN than in NIRUN (3.9\%).

A remarkable behaviour is found comparing higher NIRUN and lower AVRUN phosphorus total content in the Eastern Mediterranean, see in Figs. 11a and c the frames below the pie diagrams. In fact, phosphorus detritus in Fig. $11 \mathrm{a}$, calculated as $3.4 \%$ times $14.5 \mathrm{mmolP} \mathrm{m}^{-2}$, is equal to $0.49 \mathrm{mmolP} \mathrm{m}^{-2}$ and lower than $0.64 \mathrm{mmolP} \mathrm{m}^{-2}$, in AVRUN (Fig. 11c), given by $4.6 \%$ times $13.9 \mathrm{mmolP} \mathrm{m}^{-2}$. Moreover, the AVRUN $D_{P}$ 15 value is also higher than GARUN one $\left(0.63 \mathrm{mmolP} \mathrm{m}^{-2}\right)$.

Thus the explanation of this eastern total phosphorus reduction, in presence of atmospheric fertilization, resides in an increased bottom export due to detritus. It is worth noting that also nitrogen detritus in AVRUN (Fig. 10c) is higher than in GARUN and NIRUN (Figs. 10b and a).

20 Total western phosphorus total contents appear in line with atmospheric deposition shown in Table 3, confirming the greatest value in GARUN (Fig. 11e), intermediate in AVRUN (Fig. 11f) and the lowest in NIRUN (Fig. 11d). As in the eastern case, GARUN presents an atmospheric DIP input about three times that one in AVRUN (but now with atmospheric DIN $10 \%$ more). In the latter run, the western system experiences more oligotrophic conditions, which favour the growth of the ultraplankton and a less pronounced grazing.

Mediterranean sensitivity to atmospheric inputs

M. Pacciaroni and G. Crispi

\section{Title Page}

Abstract Introduction

Conclusions References

Tables
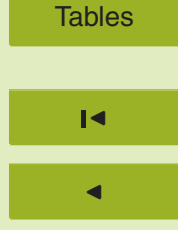

Back
Figures

$>1$

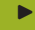

Close

Full Screen / Esc

Printer-friendly Version

Interactive Discussion 
Biomass concentrations as integrated all over the basin for 6 years of model simulation and considering the three different atmospheric inputs are shown in Fig. 12.

The three seasonal cycles of biological components show respectively quasi5 stationary evolution starting from the first year of simulation. In Fig. 12a netplankton substantially dominates starting from the second year with $0.06 \mu \mathrm{mol} \mathrm{C} \mathrm{dm}^{-3}$; looking at Fig. 12b, netplankton cells, after the first bloom during the early spring, range $0.07-0.08 \mu \mathrm{mol} \mathrm{C} \mathrm{dm}{ }^{-3}$. Also ultraplankton cells are quasi-stationary and reach higher

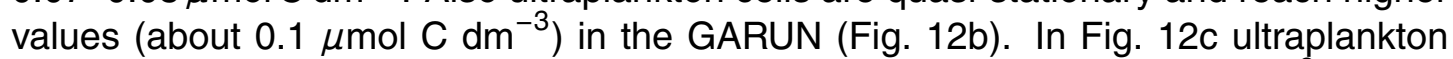
dominates the basin, showing high values that reach $0.12-0.13 \mu \mathrm{mol} \mathrm{C} \mathrm{dm}^{-3}$. There are no evident differences, among the three runs, concerning the zooplankton biomass cycles.

The ultraplankton take the largest averaged percent value of the total phytoplanktonic biomass, when considering the last three years of the simulations. Particularly in the

15 NIRUN, $S$ represents the $50.1 \%$ of the total phytoplankton, while in the GARUN it represents the $57 \%$, and it reaches its maximum value of $59 \%$ in the AVRUN. In the last three years of each run, phytoplankton community attains the greater values during late winter and spring (essentially in February, March and April). Evaluating yearly averaged vertically integrated biomass (as sum of $S$ and $L$ ), values of $2.28 \mathrm{~g} \mathrm{C} \mathrm{m}^{-2}$ in 20 the NIRUN, $2.70 \mathrm{~g} \mathrm{C} \mathrm{m}^{-2}$ in the GARUN and $2.76 \mathrm{~g} \mathrm{C} \mathrm{m}^{-2}$ in the AVRUN are obtained, in the whole Mediterranean Sea. In Table 6 vertically integrated biomass values are reported considering the western and the eastern basins in relation to the different atmospheric inputs.

Netplankton dominate the western basin with values more than three times that in 25 the eastern one and this is true for all the three simulations. On the other hand, very high values of ultraplankton are present in the eastern for about $2.2 \mathrm{~g} \mathrm{C} \mathrm{m}^{-2}$ in AVRUN, three times the western $S$ standing stock.

Zooplankton vertically integrated biomasses in the whole Mediterranean basin are

\section{BGD}

4, 909-959, 2007

Mediterranean sensitivity to atmospheric inputs

M. Pacciaroni and G. Crispi

Title Page

Abstract Introduction

Conclusions

Tables References Figures

14

4

Back

Full Screen / Esc

Printer-friendly Version

Interactive Discussion 
$0.47 \mathrm{~g} \mathrm{C} \mathrm{m}^{-2}, 0.56 \mathrm{~g} \mathrm{C} \mathrm{m}^{-2}, 0.55 \mathrm{~g} \mathrm{C} \mathrm{m}^{-2}$ looking respectively at the NIRUN, GARUN and AVRUN. In this case, there is a strong difference between the two subbasins, as it appears in Table 7 calculated western biomasses are about three times those in the eastern.

5 The western basin is characterized by a shallow nutricline at about $40 \mathrm{~m}$ and abundance in netplankton. Some regions, as the Gulf of Lions, show quite high net primary production rates. In the eastern basin the nutricline is at about $80-90 \mathrm{~m}$ and ultraplankton dominate in such an oligotrophic environment. The net primary productions and secondary ones, for the biological compartments in ECHYM, are reported in Tables 8 and 9 . These values are obtained averaging the last three years of each run in the upper $180 \mathrm{~m}$ layer.

In the western basin, GARUN catches up the highest values of the total net primary and secondary productions, respectively about $134.0 \mathrm{~g} \mathrm{C} \mathrm{m}^{-2} \mathrm{yr}^{-1}$ and $13.9 \mathrm{~g} \mathrm{C} \mathrm{m}^{-2} \mathrm{yr}^{-1}$. Considering the ultraplankton production, increments of $28 \%$ and $1542 \%$ can be estimated in GARUN $\left(24.9 \mathrm{~g} \mathrm{C} \mathrm{m}^{-2} \mathrm{yr}^{-1}\right)$ and AVRUN $\left(27.5 \mathrm{~g} \mathrm{C} \mathrm{m}^{-2} \mathrm{yr}^{-1}\right)$ with respect to NIRUN (19.4 $\left.\mathrm{g} \mathrm{C} \mathrm{m}^{-2} \mathrm{yr}^{-1}\right)$; while netplankton increase only of $6 \%$ and 3\% (Table 8).

In the eastern basin the greatest total net primary production value occurs in AVRUN, where ultraplankton $\left(55.9 \mathrm{~g} \mathrm{C} \mathrm{m}^{-2} \mathrm{yr}^{-1}\right)$ and netplankton $\left(26.3 \mathrm{~g} \mathrm{C} \mathrm{m}^{-2} \mathrm{yr}^{-1}\right)$ produc20 tions give a total of $82.2 \mathrm{~g} \mathrm{C} \mathrm{m}^{-2} \mathrm{yr}^{-1}$. In this basin, $S$ net primary production increases of $55 \%$ in GARUN and $62 \%$ in AVRUN with respect to NIRUN, while Lonly of $11 \%$ and 7\% (Table 9).

Zooplankton, grazing larger cells with greater efficiency, show secondary production values more than twice the eastern ones.

25 A peculiar response of the total net primary production in the Eastern Mediterranean is evidenced in Table 9, where AVRUN achieves higher net production than GARUN. Although this run contains lower phosphorus atmospheric inputs compared to the GARUN one, its proper oligotrophic characteristics (see Tables 2 and 3) give rise to ultraplankton community bloom and consequently more total net primary production in

BGD

4, 909-959, 2007

Mediterranean sensitivity to atmospheric inputs

M. Pacciaroni and G. Crispi

Title Page

Abstract Introduction

Conclusions

Tables References Figures

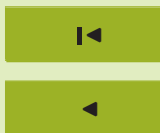

Back

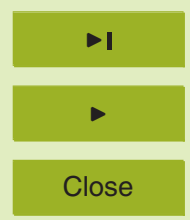

Full Screen / Esc

Printer-friendly Version

Interactive Discussion 


\section{Conclusions}

4, 909-959, 2007

Biomass estimation, based on phosphorus and nitrogen realistic atmospheric loads in the Mediterranean Sea, has been carried out by means of the three-dimensional bio5 geochemical ECHYM model, and validated using monthly 1979-1985 CZCS images.

The yearly modelled chlorophyll concentrations and integrated biomass in the upper $20 \mathrm{~m}$ and $200 \mathrm{~m}$ layers compare well with the historical data, particularly showing a mean surface chlorophyll value of $0.30 \mathrm{mg} \mathrm{Chl} \mathrm{m}^{-3}$ in the Western Mediterranean and about $0.12 \mathrm{mg} \mathrm{Chl} \mathrm{m}^{-3}$ in the eastern basin.

10 In the western transect, with nitrogen and phosphorus higher loads, the estimated increase is about $20 \%$, at $40 \mathrm{~m}$ depth. In the eastern one, the increase due to both atmospheric inputs in deep chlorophyll maxima at about $90 \mathrm{~m}$ is $25 \%$.

The standing stocks and their composition in the Mediterranean subbasins can be appreciated in terms of vertical integrated variations. The size fractionated biomass growth favours small cells, ultraplankton in the ecomodel, mainly in the oligotrophic Eastern Mediterranean. In any case the atmospheric inputs can account for 8.7$9.6 \%$ of total net primary production in the Western and of $36.5-38.8 \%$ in the Eastern Mediterranean.

The modelled primary production in the upper $180 \mathrm{~m}$ is in keeping with the field measurements and other bioptical estimates. In the western basin, ultraplankton total primary production increases, with respect to no inputs, of $28 \%$ and $42 \%$ when considering respectively GARUN and AVRUN. In the Eastern Mediterranean the effect is greater, in fact small cells show a $55 \%$ and $62 \%$ increase, respectively.

In the Western Mediterranean, netplankton and zooplankton productions are less 25 affected by both atmospheric inputs with an estimated increase of $12 \%$, in a generally more eutrophic ecosystem.

\section{Mediterranean sensitivity to atmospheric inputs}

M. Pacciaroni and G. Crispi

Title Page

Abstract Introduction

Conclusions

Tables References

14

4

Back

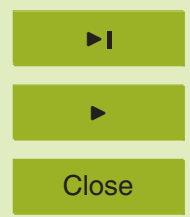

Full Screen / Esc

Printer-friendly Version

Interactive Discussion 
Atmospheric loads favour in the Eastern Mediterranean, on annual and basin average, ultraplankton species activity. In some cases, the regenerated production guided by small cells becomes more important than netplankton production, because of the greater oligotrophy in the eastern upper layer, induced by higher detritus export. Any5 way favourable growth of the small cells, due to acclimation to higher eastern typical temperatures, induces an increased net primary production.

Acknowledgements. This work has been supported by the EC ADIOS Project, Atmospheric Deposition and Impact on the Open Mediterranean Sea, EVK3 - 2000 - 00604 and by Mediterranean Forecasting System Toward Environmental Predictions, EVK3 - CT - 2002 - 00075.

10 We thank A. Crise for fruitful aid and suggestions about the ecomodel. The authors are also grateful to D. Viezzoli for helpful hints and discussions, and to M. Burca for details on yearly averaged chlorophyll data in the Western and Eastern Mediterranean transects.

We wish to thank the "Consorzio Interuniversitario del Nord Est Italiano di Calcolo Automatico" for computational support.

\section{References}

Antoine, D., Morel, A., and André, J.-M.: Algal pigment distribution and primary production in the Eastern Mediterranean as derived from coastal zone color scanner observations, J. Geophys. Res., 100(C8), 16 193-16209, 1995.

Beers, J. R.: Studies on the chemical composition of the major zooplankton groups in the

Sargasso Sea off Bermuda, Limnol. Oceanogr., 11, 520-528, 1966.

Bergametti, G., Remoundaki, E., Losno, R., Steiner, E., Chatenet, B., and Buat-Ménard, P.: Source, transport and deposition of atmospheric phosphorus over the north-Western Mediterranean, J. Atmos. Chem., 14, 501-513, 1992.

Brand, L. E. and Guillard, R. R. L.: The effects of continuous light and light intensity on the reproduction rates of twenty-two species of marine phytoplankton, J. Exp. Mar. Biol. Ecol., 50, 119-132, 1981.

Chai, F., Dugdale, R. C., Peng, T.-H., Wilkerson, F. P., and Barber, R. T.: One-dimensional ecosystem model of the equatorial Pacific upwelling system. Part I: model development and silicon and nitrogen cycle, Deep-Sea Res. II, 49, 2713-2745, 2002.

\section{BGD}

4, 909-959, 2007

Mediterranean sensitivity to atmospheric inputs

M. Pacciaroni and G. Crispi

Title Page

Abstract Introduction

Conclusions

Tables References Figures

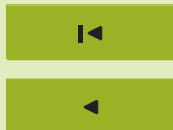

$\rightarrow$ I

Back

Close

Full Screen / Esc

Printer-friendly Version

Interactive Discussion 
Civitarese, G., Crise, A., Crispi, G., and Mosetti, R.: Circulation effects on nitrogen dynamics in the Ionian Sea, Oceanol. Acta, 19(6), 609-622, 1996.

Cloern, J. E., Grenz, C., and Vidergar-Lucas, L.: An empirical model of the phytoplankton chlorophyll:carbon ratio - the conversion factor between productivity and growth rate, Limnol. Oceanogr., 40(7), 1313-1321, 1995.

Coste, B., Le Corre, P., and Minas, H. J.: Re-evaluation of the nutrient exchanges in the Strait of Gibraltar, Deep-Sea Res., 35, 767-775, 1988.

Crise, A., Crispi, G., and Mauri, E.: A seasonal three-dimensional study of the nitrogen cycle in the Mediterranean Sea: Part I. Model implementation and numerical results, J. Mar. Syst., $10 \quad 18(1-3), 287-312,1998$.

Crise, A., Crispi, G., Melaku Canu, D., Mosetti, V., Pacciaroni, M., and Tomini, I.: A numerical assessment of the impact of the atmospheric input on the $\mathrm{N}$ and $\mathrm{P}$ cycles in the Mediterranean Sea, Geoph. Res. Abs., 5, 11284, 2003.

Crispi, G., Mosetti, R., Solidoro, C., and Crise, A.: Nutrient cycling in Mediterranean basins: 15 the role of the biological pump in the trophic regime, Ecol. Model., 138, 101-114, 2001.

Davis, C. S.: Components of the zooplankton production cycle in Mediterranean basins: the role of the biological pump in the trophic regime, J. Mar. Res., 45, 947-983, 1987.

Durrieu de Madron, X., Denis, L., Diaz, F., Garcia, N., Guieu, C., Grenz, C., Loÿe-Pilot, M. D., Ludwig, W., Moutin, T., and Raimbault, P.: Freshwater and freshwater nutrient sources Gulf 20 of Lions, France, web page http://data.ecology.su.se, 2001.

Fasham, M. J. R., Duklow, H. W., and McKelvie, S. M.: A nitrogen-based model of plankton dynamics in the oceanic mixed layer, J. Mar. Res., 48, 591-639, 1990.

Feldman, G., McClain, C., and Esaias, W.: CZCS Dataset Guide Document, web page http: //eosdata.gsfc.nasa.gov, 1994.

Gromiec, M. J.: Biochemical Demand - Dissolved Oxygen: river models, in: Application of Ecological Modelling in Environmental Management, part A, edited by: Jørgensen , S. E., pp. 131-225, Elsevier, Amsterdam, 1983.

Guerzoni, S., Chester, R., Dulac, F., Herut, B., Loye-Pilot, M.-D., Measures, C., Migon, C., Molinaroli, E., Moulin, C., Rossini, P., Saydam, C., Soudine, A., and Ziveri, P.: The role of atmospheric deposition in the biogeochemistry of the Mediterranean Sea, Progr. Oceanogr., 44(1-3), 147-190, 1999.

Hamza, W.: The Phenomenology of the Mediterranean Egyptian Coastal Area, MFSPP internal report, web page http://www.pml.ac.uk/ecomodels/oldpages/Egypt.htm, 2001.

4, 909-959, 2007

\section{Mediterranean sensitivity to atmospheric inputs}

M. Pacciaroni and G. Crispi

Title Page

Abstract Introduction

Conclusions

Tables References

Figures

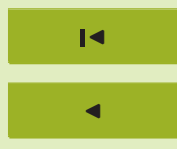

$>1$

Back

Close

Full Screen / Esc

Printer-friendly Version

Interactive Discussion 
Holland W. R.: The Role of Mesoscale Eddies in the General Circulation of the OceanNumerical Experiments Using a Wind-Driven Quasi-Geostrophic Model, J. Phys. Oceanogr., 8, 363-392, 1978.

Holling, C. S.: The functional response of predators to prey density, Mem. Entomol. Soc. Can., 45, 5-60, 1965.

Hood, R. R., Bates, N. R., Capone, D. G., and Olson, D. B.: Modelling the effect of nitrogen fixation on carbon and nitrogen fluxes at BATS, Deep-Sea Res. II, 48, 1609-1648, 2001.

Jacques, G., Minas, H. J., Minas, M., and Nival, P.: Influence des conditions hivernales sur les productions phyto- et zooplanctoniques en Méditerranée Nord-Occidentale. II. Biomasse et production phytoplanctonique, Mar. Biol., 23, 251-265, 1973.

Kana, T. M. and Glibert, P. M.: Effects of irradiances up to $2000 \mu \mathrm{E} \mathrm{m}^{-2} \mathrm{~s}^{-1}$ on marine Synechococcus WH7803: I. Growth, pigmentation, and cell composition, Deep-Sea Res., 34(4), 479-495, 1987.

Korres, G., Pinardi, N., and Lascaratos, A.: The Ocean Response to Low-Frequency Interannual Atmospheric Variability in the Mediterranean Sea. Part I: Sensitivity Experiments and Energy Analysis, J. Climate, 13, 705-731, 2000.

Kovalev, A. W., Kideys, A. E., Pavlova, E. V., Shmeleva, A. A., Skryabin, V. A., Ostrovskaya, N. A., and Uysal, Z.: Composition and abundance of zooplankton of the Eastern Mediterranean Sea, in: The Eastern Mediterranean as a Laboratory Basin for the Assesment of Contrasting Ecosystem, edited by: Malanotte-Rizzoli, P. and Eremeev, V. N., 81-95, Kluwer, the Netherlands, 1999.

Lassiter, R. R. and Kearns, D. K.: Phytoplankton population changes and nutrient fluctuations in a simple aquatic ecosystem model, in: Modeling the Eutrophication Process, edited by: Middlebrookes, E. J., Falkenberg, E. J. and Maloney, D. H., 131-138, Ann Arbor, MI., 1974.

Lefevre, D., Minas, H. J., Minas, M., Robinson, C., Williams, P. J. le B., and Woodward, E. M. S.: Review of gross community production, primary production, net community production and dark community respiration in the Gulf of Lions, Deep-Sea Res. (II), 44(3-4), 801-832, 1997.

Lévy, M., Visbeck, M., and Naik, N.: Sensitivity of primary production to different eddy parame30 terizations: A case study of the spring bloom development in the northwestern Mediterranean Sea, J. Mar. Res., 57, 427-448, 1999.

Llewellyn, C. A. and Gibb, S. W.: Intra-class variability in the carbon, pigment and biomineral content of prymnesiophytes and diatoms, Mar. Ecol. Prog. Ser., 193, 33-44, 2000.
BGD

4, 909-959, 2007

Mediterranean

sensitivity to

atmospheric inputs

M. Pacciaroni and
G. Crispi

Title Page

Abstract

Introduction

Conclusions

Tables

References

Figures

14

4

Back

Full Screen / Esc

Printer-friendly Version

Interactive Discussion 
Loÿe-Pilot, M.-D., Martin, J.-M., and Morelli, J.: Atmospheric input of inorganic nitrogen to the Western Mediterranean, Biogeochemistry, 9, 117-134, 1990.

Markaki, Z., Oikonomou, K., Kocak, M., Kouvarakis, G., Chaniotaki, A., Kubilay, N., and Mihalopoulos, N.: Atmospheric deposition of inorganic phosphorus in the Levantine Basin,

5 Eastern Mediterranean: Spatial and temporal variability and its role in seawater productivity, Limnol. Oceanogr., 48(4), 1557-1568, 2003.

Martin, J.-M. and Barth, H. (Eds.): EROS 2000 (European River Ocean System) Fifth Workshop on the North-West Mediterranean Sea Hamburg (Germany), 28-30 March 1994, Water Pollution Research Report, 32, pp. 318, published by the European Commission, Luxembourg, 1995.

McLaren, I. A.: Some relationships between temperature and egg size, body size, development rate and fecundity of the copepod Pseudocalanus, Limnol. Oceanogr., 10, 528-538, 1965.

MEDAR Group: MEDATLAS 2002, MAS3-CT98-0174 \& ERBIC20-CT98-0103, CD Rom 3, 2002.

15 Nival, P., Nival, S., and Thiriot, A. : Influence des conditions hivernales sur les productions phyto- et zooplanctoniques en Méditerranée Nord-Occidentale. V. Biomasse et production zooplanctonique -relations phyto-zooplancton, Mar. Biol., 31, 249-270, 1975.

Pacciaroni, M. and Crispi, G.: OGS Internal Technical Report 15-2003/OGA 7, 38-41, 2003.

Petihakis, G., Triantafyllou, G., Allen, J., Hoteit, I., and Dounas, C.: Modeling the spatial and temporal variability of the Cretan Sea ecosystem, J. Mar. Syst., 36(3-4), 173-196, 2002.

Rabitti, S., Civitarese, G., and Ribera, M.: Data Report Cruise POEM-BC - October 1991 Ionian Basin and Sicily Channel: II. Chemical and Biological Data, Tech. Report No. 13/94CNR/IBM, 1994.

Redfield, A. C., Ketchum, B. H., and Richards, F. A.: The influence of Sea Water, in: The Sea, vol. 2, edited by: Hill, M. N., pp. 26-77, Interscience, New York, 1963.

Ribera d'Alcalà, M., Civitarese, G., Conversano, F., and Cavezza, R.: Nutrient ratios and fluxes hint at overlooked processes in the Mediterranean Sea, J. Geoph. Res., 108(C9), 8106, doi:10.1029/2002JC001650, 2003.

Rixen, M., Beckers, J.-M., Brankart, J.-M., and Brasseur, P.: A numerically efficient data analysis method with error map generation, Ocean Modelling, 2(1-2), 45-60, 2001.

Sakshaug, E., Andresen, K., and Kiefer, D. A.: A steady state description of growth and light absorption in the marine planktonic diatom Skeletonema costatum, Limnol. Oceanogr., 34(1), 198-205, 1989.

BGD

4, 909-959, 2007

Mediterranean

sensitivity to

atmospheric inputs

M. Pacciaroni and

G. Crispi

Title Page

Abstract

Introduction

Conclusions

Tables

References

Figures

14

4

Back

Full Screen / Esc

Printer-friendly Version

Interactive Discussion 
Semtner Jr., A. J. and Mintz, Y.: Numerical Simulation of the Gulf Stream and Mid-Ocean Eddies, J. Phys. Oceanogr., 7, 208-230, 1977.

Siokou-Frangou, I., Bianchi, M., Christaki, U., Christou, E. D., Giannakourou, A., Gotsis, O., Ignatiades, L., Pagou, K., Pitta, P., Psarra, S., Souvermezoglou, E., Van Wambeke, F., and

5 Zervakis, V.: Carbon flow in the planktonic food web along a gradient of oligotrophy in the Aegean Sea (Mediterranean Sea), J. Mar. Syst., 33-34, 335-353, 2002.

Steele, J. H.: Environmental control of photosynthesis in the sea, Limnol. Oceanogr., 7, 137150, 1962.

Sturm, B., Barale, V., Larkin, D., Andersen, J. H., and Turner, M.: OCEANcode: the complete set of algorithms and models for the level-2 processing of European CZCS historical data, Int. J. Remote Sens., 20(7), 1219-1248, 1999.

Turley, C. M., Bianchi, M., Christaki, U., Conan, P., Harris, J. R. W., Psarra, S., Ruddy, G., Stutt, E. D., Tselepides, A., and Van Wanbeke, F.: Relationship between primary producers and bacteria in an oligotrophic sea - the Mediterranean and biogeochemical implications, Mar. Ecol. Progr. Ser., 193, 11-18, 2000.

Tusseau-Vuillemin, Mortier, L., and Herbaut, C.: Modeling nitrate fluxes in an open coastal environment (Gulf of Lions): Transport versus biogeochemical processes, J. Geoph. Res., 103(C4), 7693-7708, 1998.

Vidussi, F., Claustre, H., Manca, B. B., Luchetta, A., and Marty, J.-C.: Phytoplankton pigment distribution in relation to upper thermocline circulation in the Eastern Mediterranean Sea during winter, J. Geophys. Res., 106(C9), 19 939-19 956, 2001.

Wen, Y. H. and Peters, R. H.: Empirical models of phosphorus and nitrogen excretion rates by zooplankton, Limnol. Oceanogr., 39(7), 1669-1679, 1994.

Wrobleski, J. S.: A model of phytoplankton plume formation during variable Oregon upwelling, J. Mar. Res., 35(2), 357-394, 1977.

Zakardjian, B. and Prieur, L.: A numerical study of primary production related to vertical turbulent diffusion with special reference to vertical motions of the phytoplankton cells in nutrient and light fields, J. Mar. Syst., 5, 267-295, 1994.

Zavatarelli, M., Baretta, J. W., Baretta-Bekker, J. G., and Pinardi, N.: The dynamics of the $30 \quad$ Adriatic Sea ecosystem: an idealized model study, Deep-Sea Res., 47, 937-970, 2000.

\section{Mediterranean sensitivity to atmospheric inputs}

M. Pacciaroni and G. Crispi

Title Page

Abstract Introduction

Conclusions

Tables References Figures

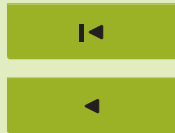

$\rightarrow$ I

Back

Close

Full Screen / Esc

Printer-friendly Version

Interactive Discussion 
Table 1. Parameters of the ecosystem formulation. The following terms: $k_{r}, k_{e}, k_{\mathrm{exz}}, k_{\mathrm{dec}}, k_{\mathrm{nit}}$ generate the corresponding $k_{r}^{*}, k_{e}^{*}, k_{\mathrm{exz}}^{*}, k_{\mathrm{dec}}^{*}, k_{\mathrm{nit}}^{*}$, when multiplied by the Arrhenius factor.

\begin{tabular}{|c|c|c|c|c|}
\hline Parameter & Definition & Value & Unit & Reference \\
\hline$\mu_{S}$ & Maximum growth rate of ultraplankton & $1.60 \times 10^{-5}$ & $\mathrm{~s}^{-1}$ & Kana and Glibert (1987) \\
\hline$k_{P S}$ & Phosphorus half-saturation of ultraplankton & 0.015 & $\mu \mathrm{mol} \mathrm{P} \mathrm{dm}{ }^{-3}$ & Calibration \\
\hline$k_{N S}$ & Nitrogen half-saturation of ultraplankton & 0.15 & $\mu \mathrm{mol} \mathrm{N} \mathrm{dm}{ }^{-3}$ & Calibration \\
\hline$k_{A S}$ & Ammonia half-saturation of ultraplankton & 0.15 & $\mu \mathrm{mol} \mathrm{N} \mathrm{dm}{ }^{-3}$ & Calibration \\
\hline$\psi_{S}$ & Ammonia inhibition coefficient for ultraplankton & 1.5 & $\mu \mathrm{mol} \mathrm{N} \mathrm{dm}{ }^{-3}$ & Wrobleski (1977) \\
\hline$\mu_{L}$ & Maximum growth rate of netplankton & $3.20 \times 10^{-5}$ & $\mathrm{~s}^{-1}$ & Brand and Guillard (1981) \\
\hline$k_{P L}$ & Phosphorus half-saturation of netplankton & 0.025 & 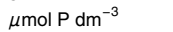 & Calibration \\
\hline$k_{N L}$ & Nitrogen half-saturation of netplankton & 0.25 & $\mu \mathrm{mol} \mathrm{N} \mathrm{dm}{ }^{-3}$ & Calibration \\
\hline$k_{A L}$ & Ammonia half-saturation of netplankton & 0.25 & $\mu \mathrm{mol} \mathrm{N} \mathrm{dm}{ }^{-3}$ & Calibration \\
\hline$\psi_{L}$ & Ammonia inhibition coefficient for netplankton & 1.5 & $\mu \mathrm{mol} \mathrm{N} \mathrm{dm}{ }^{-3}$ & Wrobleski (1977) \\
\hline$k_{\text {nit }}$ & Nitrification rate & $1.11 \times 10^{-5}$ & $\mathrm{~s}^{-1}$ & Zakardjian and Prieur (1994) \\
\hline$k_{A O}$ & Nitrification half-saturation for oxygen & 31.25 & $\mu \mathrm{mol} O \mathrm{dm}^{-3}$ & Calibration \\
\hline$R_{N C}$ & Nitrogen to carbon ratio in phytoplankton & 0.1509 & $\mu \mathrm{mol} \mathrm{N}(\mu \mathrm{mol} \mathrm{C})^{-1}$ & Redfield et al. (1963) \\
\hline$R_{P C}$ & Phosphorus to carbon ratio in phytoplankton & 0.0094 & $\mu \mathrm{mol} \mathrm{P}(\mu \mathrm{mol} \mathrm{C})^{-1}$ & Redfield et al. (1963) \\
\hline$r_{N C}$ & Nitrogen to carbon ratio in zooplankton & 0.25 & $\mu \mathrm{mol} \mathrm{N}(\mu \mathrm{mol} \mathrm{C})^{-1}$ & Beers (1966) \\
\hline$r_{P C}$ & Phosphorus to carbon ratio in zooplankton & 0.0208 & $\mu \mathrm{mol} P(\mu \mathrm{mol} \mathrm{C})^{-1}$ & Beers (1966) \\
\hline$R_{O C}$ & Oxygen to carbon ratio & 1 & $\mu \mathrm{mol} O(\mu \mathrm{mol} \mathrm{C})^{-1}$ & Zakardjian and Prieur (1994) \\
\hline$R_{\text {nit }}$ & Nitrification oxygen & 2 & $\mu \mathrm{mol} O(\mu \mathrm{mol} \mathrm{N})^{-1}$ & Zakardjian and Prieur (1994) \\
\hline$k_{\operatorname{dec} C}$ & Carbon remineralization rate & $0.59 \times 10^{-6}$ & $\mathrm{~s}^{-1}$ & Calibration \\
\hline$k_{\operatorname{dec} N}$ & Nitrogen remineralization rate & $1.18 \times 10^{-6}$ & $\mathrm{~s}^{-1}$ & Calibration \\
\hline$k_{\mathrm{dec} P}$ & Phosphorus remineralization rate & $2.36 \times 10^{-6}$ & $\mathrm{~s}^{-1}$ & Calibration \\
\hline$k_{r s}$ & Ultraplankton respiration rate & $0.068 \times 10^{-6}$ & $\mathrm{~s}^{-1}$ & Calibration \\
\hline$k_{r L}$ & Netplankton respiration rate & $0.127 \times 10^{-6}$ & $s^{-1}$ & Sakshaug et al. (1989) \\
\hline$k_{p s}$ & Ultraplankton exudation rate & $0.289 \times 10^{-6}$ & $s^{-1}$ & Calibration \\
\hline$k_{e l}$ & Netplankton exudation rate & $0.359 \times 10^{-6}$ & $\mathrm{~s}^{-1}$ & Sakshaug et al. (1989) \\
\hline$k_{\mathrm{exz}}$ & Zooplankton excretion rate & $0.289 \times 10^{-6}$ & $\mathrm{~s}^{-1}$ & Wen and Peters (1994) \\
\hline$\varepsilon_{S}$ & Ultraplankton efficiency & 0.25 & & Calibration \\
\hline$\varepsilon_{L}$ & Netplankton efficiency & 0.40 & & Calibration \\
\hline$g$ & Zooplankton grazing rate & $1.157 \times 10^{-5}$ & $\mathrm{~s}^{-1}$ & Fasham et al. (1990) \\
\hline$\alpha$ & Preference coefficient & & & Calibration \\
\hline$\alpha_{\beta}$ & Newtonian restoration time & $2.3148 \times 10^{-6}$ & $\mathrm{~s}^{-1}$ & Calibration \\
\hline$k_{H}$ & Grazing half-saturation & 4 & 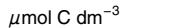 & Fasham et al. (1990) \\
\hline$d_{S}$ & Ultraplankton lysis and mortality & $0.222 \times 10^{-6}$ & $\mathrm{~s}^{-1}$ & Calibration \\
\hline$d_{1}$ & Netplankton lysis and mortality & $0.555 \times 10^{-6}$ & $s^{-1}$ & Sakshaug et al. (1989) \\
\hline$d_{z}$ & Zooplankton mortality & $0.289 \times 10^{-6}$ & $\mathrm{~s}^{-1}$ & Davis (1987) \\
\hline$\xi$ & Arrhenius base & 1.07 & $\exp \left({ }^{\circ} C^{-1}\right)$ & McLaren (1965) \\
\hline$\theta_{0}$ & Arrhenius reference temperature & 20 & ${ }^{\circ} \mathrm{C}$ & McLaren (1965) \\
\hline$\theta_{S \max }$ & Maximum ultraplankton temperature & 30 & ${ }^{\circ} \mathrm{C}$ & Calibration \\
\hline$\theta_{S}$ & Ultraplankton optimal temperature & 19.5 & ${ }^{\circ} \mathrm{C}$ & Calibration \\
\hline$b_{s}$ & Ultraplankton temperature coefficient & 0.1157 & ${ }^{\circ} \mathrm{C}$ & Calibration \\
\hline$\theta_{L \max }$ & Maximum netplankton temperature & 24 & ${ }^{\circ} \mathrm{C}$ & Calibration \\
\hline$\theta_{\perp}^{\max }$ & Netplankton optimal temperature & 16.5 & ${ }^{\circ} \mathrm{C}$ & Calibration \\
\hline & Netplankton temperature coefficient & 0.1157 & ${ }^{\circ} \mathrm{C}$ & Calibration \\
\hline$I_{\text {opt }}^{L} / I_{0}$ & Optimum light ratio & 0.5 & & Steele (1962) \\
\hline$R_{S L}$ & Ultraplankton $\mathrm{Chl} / \mathrm{C}$ transformation quota & 2 & & Llewellyn and Gibb (2000) \\
\hline$k_{\text {aer }}$ & Reareation surface coefficient & $1.157 \times 10^{-5}$ & $s^{-1}$ & Gromiec (1983) \\
\hline
\end{tabular}

BGD

4, 909-959, 2007

\section{Mediterranean sensitivity to atmospheric inputs}

M. Pacciaroni and G. Crispi

Title Page

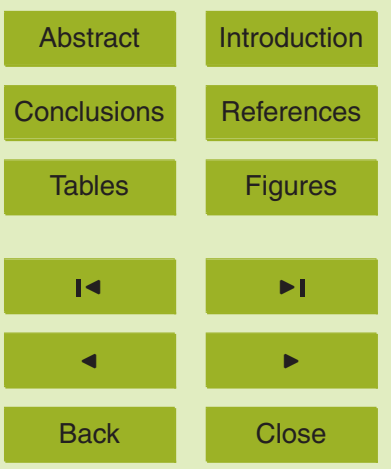

Full Screen / Esc

Printer-friendly Version

Interactive Discussion 
BGD

4, 909-959, 2007

\section{Mediterranean \\ sensitivity to \\ atmospheric inputs}

M. Pacciaroni and

G. Crispi

Table 2. Atmospheric nitrate deposition in the main three regions of the Mediterranean Sea. The three run loads are shown in order to appreciate the different nitrate contribution.

\begin{tabular}{cccc}
\hline $\begin{array}{c}\text { DIN } \\
\text { ATMOSPHERIC } \\
\text { INPUTS }\end{array}$ & $\begin{array}{c}\text { Western } \\
\text { Mediterranean } \\
6^{\circ} \mathrm{W}-7.25^{\circ} \mathrm{E} \\
\left(\mu \mathrm{mol} \mathrm{N} \mathrm{dm} \mathrm{dm}^{-3} \mathrm{~s}^{-1}\right)\end{array}$ & $\begin{array}{c}\text { Central } \\
\text { Mediterranean } \\
7.5^{\circ} \mathrm{E}-18.0^{\circ} \mathrm{E} \\
\left(\mu \mathrm{mol} \mathrm{N} \mathrm{dm} \mathrm{m}^{-3}\right)\end{array}$ & $\begin{array}{c}\text { Eastern } \\
\text { Mediterranean } \\
18.25^{\circ} \mathrm{E}-35.75^{\circ} \mathrm{E} \\
\left(\mu \mathrm{mol} \mathrm{N} \mathrm{dm} \mathrm{s} \mathrm{m}^{-3}\right)\end{array}$ \\
\hline NIRUN & - & - & - \\
GARUN & $12.55 \times 10^{-8}$ & $9.93 \times 10^{-8}$ & $8.63 \times 10^{-8}$ \\
AVRUN & $10.78 \times 10^{-8}$ & $10.35 \times 10^{-8}$ & $9.93 \times 10^{-8}$ \\
\hline
\end{tabular}

Title Page

Abstract

Introduction

Conclusions

References

Tables

Figures

14

$>$ I

4

Back

Close

Full Screen / Esc

Printer-friendly Version

Interactive Discussion 
BGD

4, 909-959, 2007

\section{Mediterranean \\ sensitivity to \\ atmospheric inputs}

M. Pacciaroni and

G. Crispi

Table 3. Atmospheric phosphate deposition in the main three regions of the Mediterranean Sea. The three run loads are shown in order to appreciate the different phosphorus contribution.

\begin{tabular}{cccc}
\hline $\begin{array}{c}\text { DIN } \\
\text { ATMOSPHERIC } \\
\text { INPUTS }\end{array}$ & $\begin{array}{c}\text { Western } \\
\text { Mediterranean } \\
6^{\circ} \mathrm{W}-7.25^{\circ} \mathrm{E} \\
\left(\mu \mathrm{mol} \mathrm{N} \mathrm{dm} \mathrm{m}^{-3} \mathrm{~s}^{-1}\right)\end{array}$ & $\begin{array}{c}\text { Central } \\
\text { Mediterranean } \\
7.5^{\circ} \mathrm{E}-18.0^{\circ} \mathrm{E} \\
\left(\mu \mathrm{mol} \mathrm{N} \mathrm{dm} \mathrm{m}^{-3}\right)\end{array}$ & $\begin{array}{c}\text { Eastern } \\
\text { Mediterranean } \\
18.25^{\circ} \mathrm{E}-35.75^{\circ} \mathrm{E} \\
\left(\mu \mathrm{mol} \mathrm{N} \mathrm{dm} \mathrm{s}^{-1}\right)\end{array}$ \\
\hline NIRUN & - & - & - \\
GARUN & $3.58 \times 10^{-9}$ & $2.85 \times 10^{-9}$ & $2.22 \times 10^{-9}$ \\
AVRUN & $1.40 \times 10^{-9}$ & $1.00 \times 10^{-9}$ & $0.61 \times 10^{-9}$ \\
\hline
\end{tabular}


BGD

4, 909-959, 2007

\section{Mediterranean sensitivity to atmospheric inputs}

M. Pacciaroni and G. Crispi

Table 4. Western and eastern chlorophyll:carbon ratios in ultraplankton and netplankton cells for the upper $200 \mathrm{~m}$ layer.

\begin{tabular}{lcc}
\hline & $\begin{array}{c}\text { Western } \\
\text { Mediterranean }\end{array}$ & $\begin{array}{c}\text { Eastern } \\
\text { Mediterranean }\end{array}$ \\
\hline Ultraplankton Chl:C & 0.01 & 0.0067 \\
Netplankton Chl:C & 0.02 & 0.0133 \\
\hline
\end{tabular}

Western

Title Page

Abstract Introduction

Conclusions References

Tables Figures

14 $>1$

4

Back

Close

Full Screen / Esc

Printer-friendly Version

Interactive Discussion 
BGD

4, 909-959, 2007

\section{Mediterranean sensitivity to atmospheric inputs}

M. Pacciaroni and G. Crispi

Table 5. Surficial averaged chlorophyll concentrations in the upper $20 \mathrm{~m}$ (two levels), of NIRUN, obtained from VIM climatology and JRC CZCS satellite measurements. Coastal areas shallower than $200 \mathrm{~m}$ are excluded.

\begin{tabular}{ccc}
\hline & $\begin{array}{c}\text { Western } \\
\text { Mediterranean } \\
\left(\mathrm{mg} \mathrm{Chl} \mathrm{m}^{-3}\right)\end{array}$ & $\begin{array}{c}\text { Eastern } \\
\text { Mediterranean } \\
\left(\mathrm{mg} \mathrm{Chl} \mathrm{m}^{-3}\right)\end{array}$ \\
\hline NIRUN & 0.27 & 0.09 \\
GARUN & 0.31 & 0.13 \\
AVRUN & 0.32 & 0.14 \\
VIM & 0.20 & 0.07 \\
CZCS & 0.26 & 0.12 \\
\hline
\end{tabular}

Title Page

Abstract Introduction

Conclusions References

Tables Figures

14

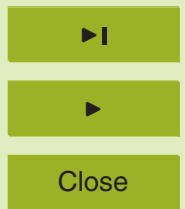

Back 
BGD

4, 909-959, 2007

\section{Mediterranean sensitivity to atmospheric inputs}

M. Pacciaroni and G. Crispi

Table 6. Total biomass (ultraplankton plus netplankton) in the Western and Eastern Mediterranean, according to the three different simulations.

\begin{tabular}{ccc}
\hline RUN & $\begin{array}{c}\text { Western basin } \\
\left(\mathrm{g} \mathrm{C} \mathrm{m}^{-2}\right)\end{array}$ & $\begin{array}{c}\text { Eastern basin } \\
\left(\mathrm{g} \mathrm{C} \mathrm{m}^{-2}\right)\end{array}$ \\
\hline NIRUN & 2.43 & 2.14 \\
GARUN & 2.51 & 2.81 \\
AVRUN & 2.55 & 2.89 \\
\hline
\end{tabular}

Title Page

Abstract Introduction

Conclusions References

14 $>1$

4

Back

Close

Full Screen / Esc

Printer-friendly Version 
BGD

4, 909-959, 2007

\section{Mediterranean sensitivity to atmospheric inputs}

M. Pacciaroni and G. Crispi

Table 7. Total zooplankton biomass in the Western and Eastern Mediterranean, according to the three different simulations.

\begin{tabular}{ccc}
\hline RUN & $\begin{array}{c}\text { Western basin } \\
\left(\mathrm{g} \mathrm{C} \mathrm{m}^{-2}\right)\end{array}$ & $\begin{array}{c}\text { Eastern basin } \\
\left(\mathrm{g} \mathrm{C} \mathrm{m}^{-2}\right)\end{array}$ \\
\hline NIRUN & 0.84 & 0.26 \\
GARUN & 0.95 & 0.33 \\
AVRUN & 0.93 & 0.33 \\
\hline
\end{tabular}

Title Page

Abstract

Conclusions

Tables

14

$<$

Back

Full Screen / Esc

Printer-friendly Version 
Table 8. Ultraplankton, netplankton, total primary and secondary productions in the Western Mediterranean Sea. The integration is made in the upper $180 \mathrm{~m}$ layer for NIRUN, GARUN and AVRUN, averaging the last three of 6 years model simulation. Turley et al. (2000) estimate $183 \mathrm{gC} \mathrm{m}^{-2} \mathrm{yr}^{-1}$ of total primary production from in situ data; Antoine et al. (1995) give $157.7 \mathrm{gC} \mathrm{m}^{-2} \mathrm{yr}^{-1}$ of total primary productions by means of 1-D bioptical model applied upon satellite data.

\begin{tabular}{ccccc}
\hline $\begin{array}{c}\text { ATMOSPHERIC } \\
\text { INPUTS }\end{array}$ & $\begin{array}{c}\text { Ultraplankton } \\
\text { Primary } \\
\text { Production } \\
\left(\mathrm{g} \mathrm{C} \mathrm{m}^{-2} \mathrm{yr}^{-1}\right)\end{array}$ & $\begin{array}{c}\text { Netplankton } \\
\text { Primary } \\
\text { ProductionProduction } \\
\left(\mathrm{g} \mathrm{C} \mathrm{m}^{-2} \mathrm{yr}^{-1}\right)\end{array}$ & $\begin{array}{c}\text { Total Net } \\
\text { Primary } \\
\text { Production } \\
\left(\mathrm{g} \mathrm{C} \mathrm{m}^{-2} \mathrm{yr}^{-1}\right)\end{array}$ & $\begin{array}{c}\text { Zooplankton } \\
\text { Secondary }\end{array}$ \\
$\left(\mathrm{g} \mathrm{C} \mathrm{m}^{-2} \mathrm{yr}^{-1}\right)$
\end{tabular}

\section{Mediterranean \\ sensitivity to \\ atmospheric inputs}

M. Pacciaroni and

G. Crispi

Title Page

Abstract

Introduction

Conclusions

References

Tables

Figures

14

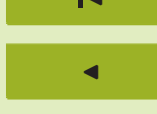

Back

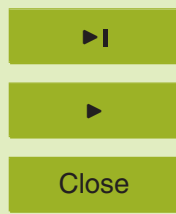

Full Screen / Esc

Printer-friendly Version

Interactive Discussion 
Table 9. Ultraplankton, netplankton, total primary and secondary productions in the Eastern Mediterranean Sea. The integration is made in the upper $180 \mathrm{~m}$ layer for NIRUN, GARUN and AVRUN, averaging the last three of 6 years model simulation. Turley et al. (2000) estimate $55 \mathrm{gC} \mathrm{m}^{-2} \mathrm{yr}^{-1}$ of total primary production from in situ data; Antoine et al. (1995) give $109.4 \mathrm{gC} \mathrm{m}^{-2} \mathrm{yr}^{-1}$ of total primary productions by means of 1-D bioptical model applied upon satellite data.

\begin{tabular}{ccccc}
\hline $\begin{array}{c}\text { ATMOSPHERIC } \\
\text { INPUTS }\end{array}$ & $\begin{array}{c}\text { Ultraplankton } \\
\text { Primary } \\
\text { Production } \\
\left(\mathrm{g} \mathrm{C} \mathrm{m}^{-2} \mathrm{yr}^{-1}\right)\end{array}$ & $\begin{array}{c}\text { Netplankton } \\
\text { Primary } \\
\text { ProductionProduction } \\
\left(\mathrm{g} \mathrm{C} \mathrm{m}^{-2} \mathrm{yr}^{-1}\right)\end{array}$ & $\begin{array}{c}\text { Total Net } \\
\text { Primary } \\
\text { Production } \\
\left(\mathrm{g} \mathrm{C} \mathrm{m}^{-2} \mathrm{yr}^{-1}\right)\end{array}$ & $\begin{array}{c}\text { Zooplankton } \\
\text { Secondary }\end{array}$ \\
$\left(\mathrm{g} \mathrm{C} \mathrm{m}^{-2} \mathrm{yr}^{-1}\right)$ \\
\hline NIRUN & 34.5 & 24.7 & 59.2 & 4.0 \\
GARUN & 53.4 & 27.4 & 80.8 & 5.3 \\
AVRUN & 55.9 & 26.3 & 82.2 & 5.2 \\
\hline
\end{tabular}

\section{Mediterranean sensitivity to atmospheric inputs}

M. Pacciaroni and G. Crispi

Title Page

Abstract Introduction

Conclusions References

Tables Figures

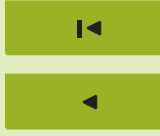

Back

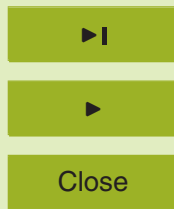

Full Screen / Esc

Printer-friendly Version

Interactive Discussion 
BGD

4, 909-959, 2007

\section{Mediterranean sensitivity to atmospheric inputs}

M. Pacciaroni and G. Crispi

Title Page

Abstract Introduction

Conclusions

References

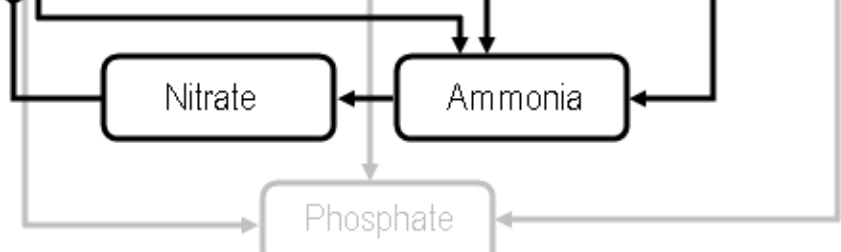

Tables

Figures

14

- I

4

Back

Close

Full Screen / Esc

Printer-friendly Version

Interactive Discussion 


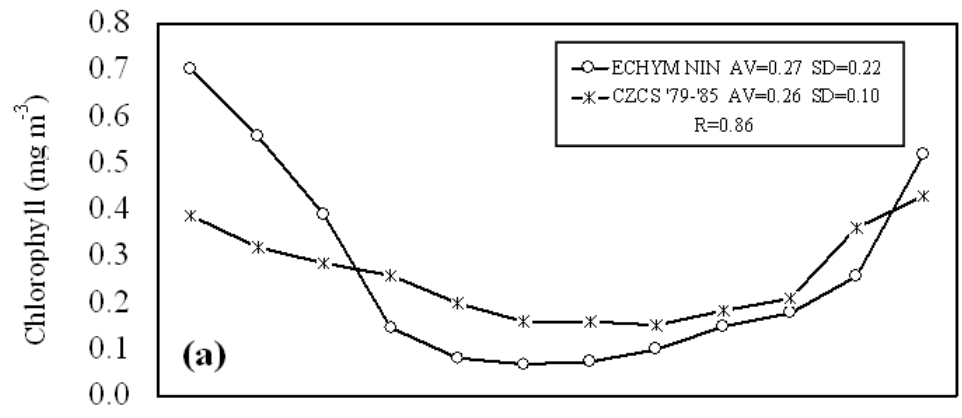

\section{BGD}

4, 909-959, 2007

\section{Mediterranean \\ sensitivity to atmospheric inputs}

M. Pacciaroni and G. Crispi

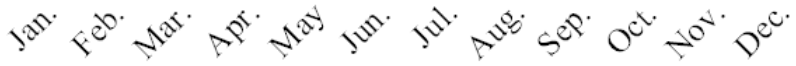

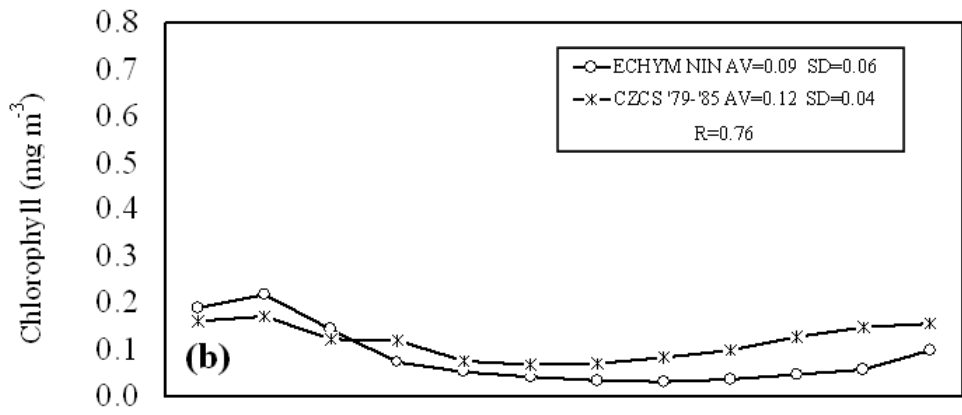

Title Page

Abstract

Conclusions

Tables

14

4

Back
Introduction

References

Figures

$\rightarrow$

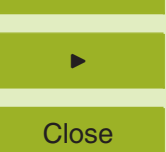

Full Screen / Esc

Printer-friendly Version 


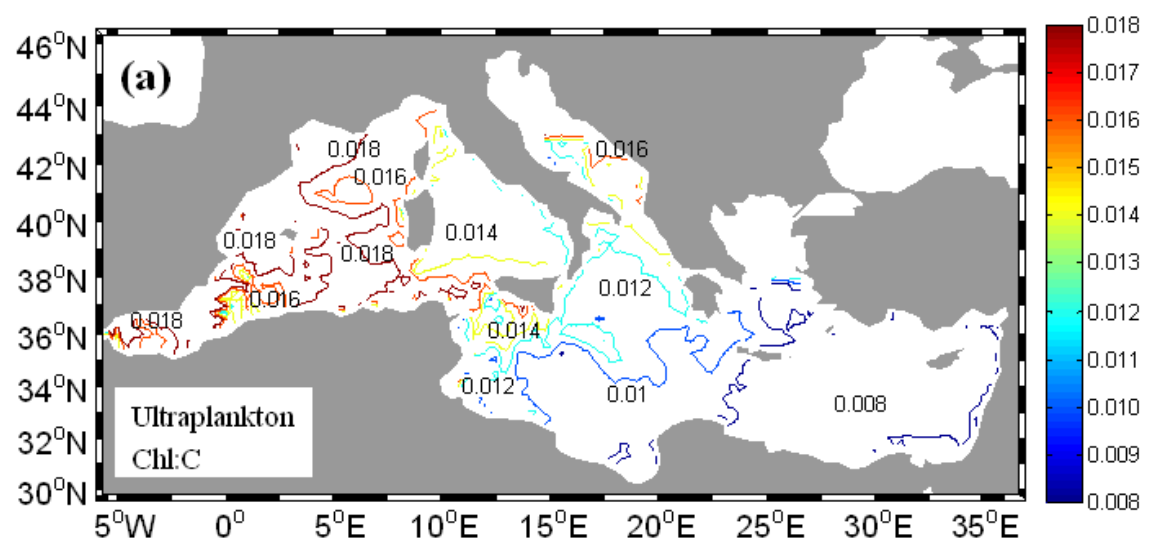

\section{BGD}

4, 909-959, 2007

\section{Mediterranean \\ sensitivity to atmospheric inputs}

M. Pacciaroni and G. Crispi

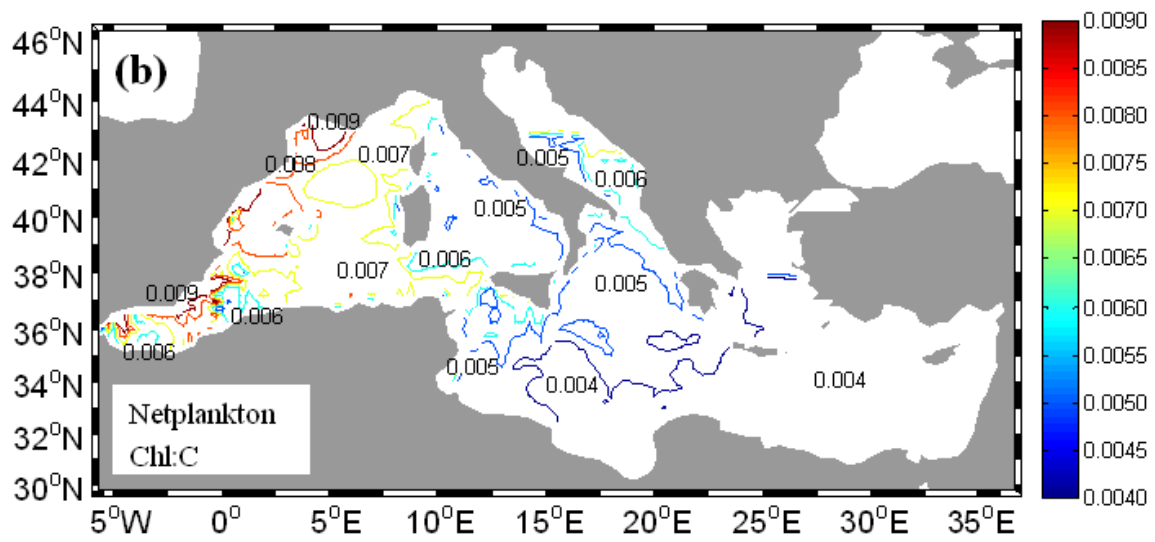

Title Page

Abstract

Conclusions

Tables

14

4

Back

Full Screen / Esc

Printer-friendly Version

Interactive Discussion

Fig. 3. Surficial (0-20 m) annual mean chlorophyll to carbon ratio maps relative to ultraplankton (a) and netplankton (b) in the case of GARUN simulation. Northern Adriatic and Aegean are blank in correspondence to the biochemical buffer zones. 
BGD

4, 909-959, 2007
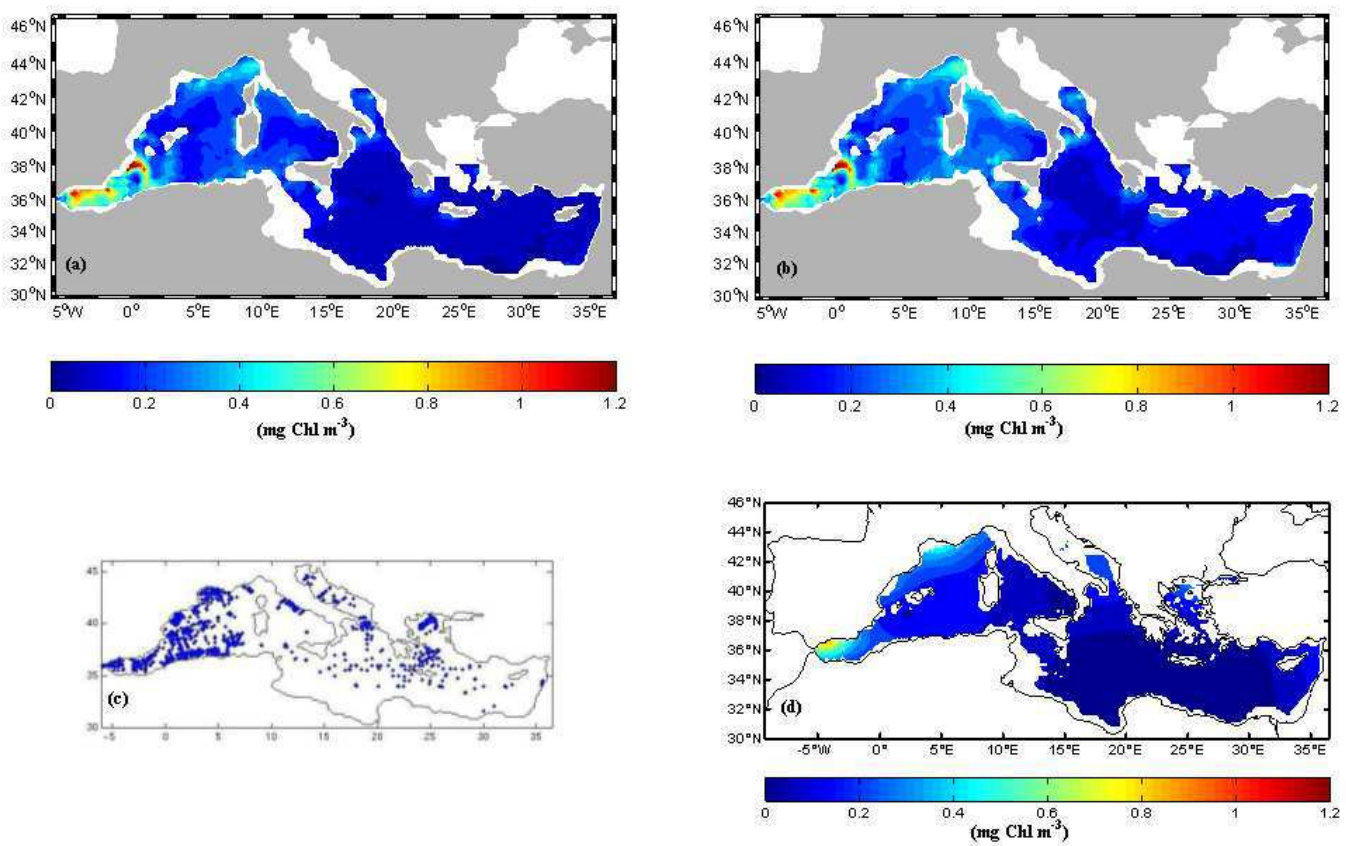

Fig. 4. Upper $20 \mathrm{~m}$ layer yearly averaged chlorophyll concentrations for NIRUN (a) and GARUN (b). White areas in Adriatic and Aegean Sea corresponds to restored buffer zones, see text for details. The MEDAR/MEDATLAS II collected stations (c) give, after interpolation by VIM, the $10 \mathrm{~m}$ yearly averaged chlorophyll concentration map (d).

\section{Mediterranean \\ sensitivity to atmospheric inputs}

M. Pacciaroni and G. Crispi

\section{Title Page}

\section{Abstract}

Conclusions

Tables

14

4

Back
Introduction

References

Figures

$\rightarrow$

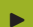

Close
Full Screen / Esc

Printer-friendly Version

Interactive Discussion 
BGD

4, 909-959, 2007
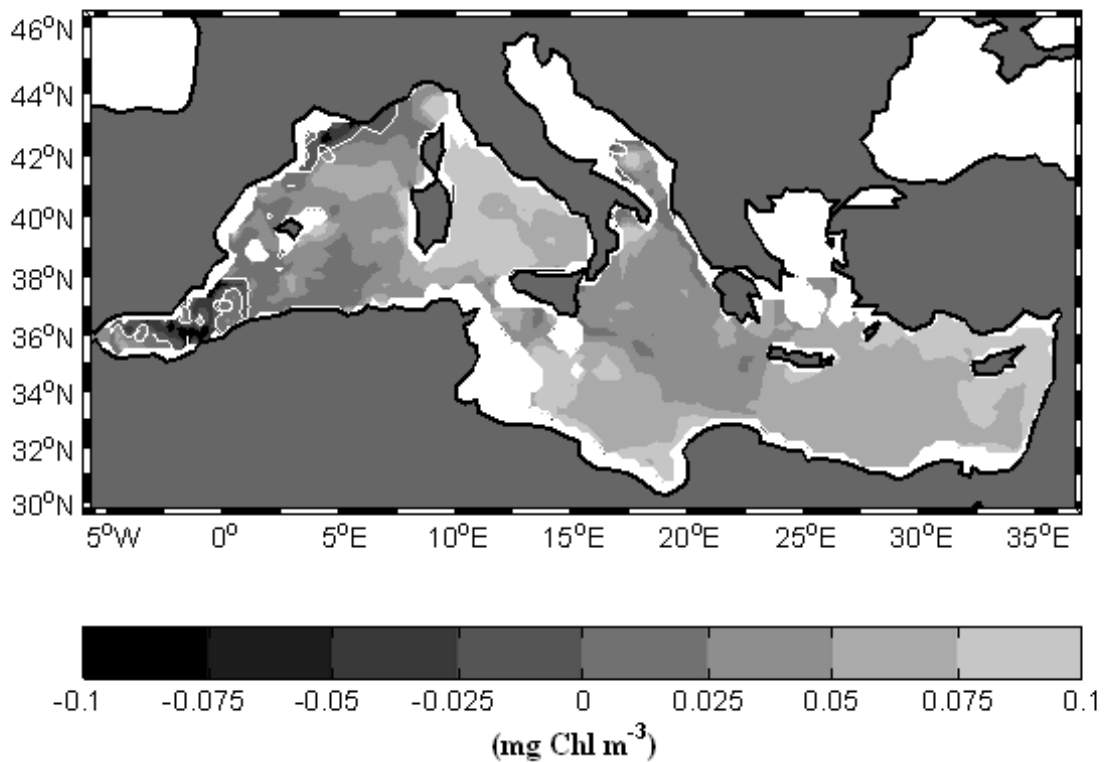

Fig. 5. Annual mean anomalies ( $\mathrm{mg} \mathrm{Chl} \mathrm{m}^{-3}$ ), GARUN-NIRUN, at $10 \mathrm{~m}$ depth. Northern Adriatic and Aegean are blank because assumed as buffer zones without biochemical fluxes. Zero anomaly line is contoured in white.

\section{Mediterranean \\ sensitivity to atmospheric inputs}

M. Pacciaroni and G. Crispi

\section{Title Page}

\section{Abstract}

Conclusions

Tables

14

Back

Full Screen / Esc

Printer-friendly Version 


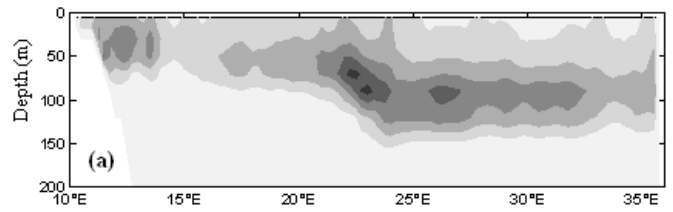

BGD

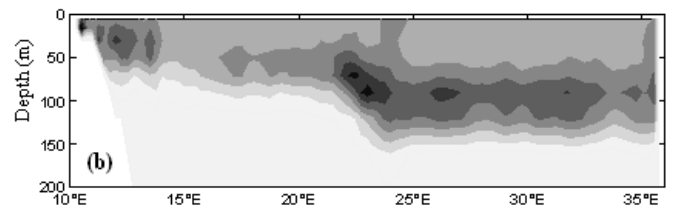

4, 909-959, 2007

\section{Mediterranean sensitivity to atmospheric inputs}

M. Pacciaroni and G. Crispi

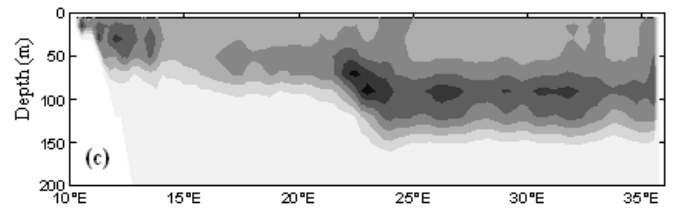

Title Page

Abstract Introduction

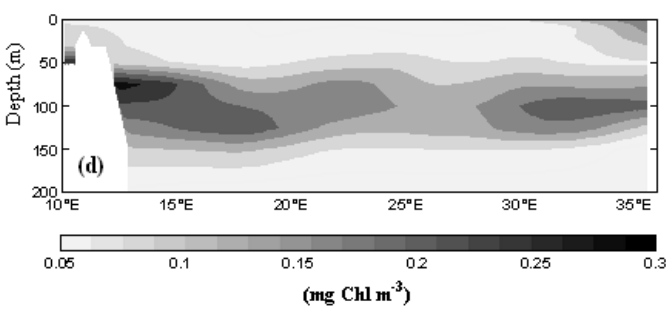

Conclusions

References

Tables

Figures

14

-1

4

Back

Close

Full Screen / Esc

Zonal transect at $34^{\circ} \mathrm{N}$

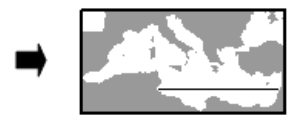

Printer-friendly Version

Fig. 6. Zonal transect of the yearly averaged chlorophyll $\left(\mathrm{mg} \mathrm{Chl} \mathrm{m}^{-3}\right)$ at $34^{\circ} \mathrm{N}$ in the eastern basin in the upper $200 \mathrm{~m}$. NIRUN (a), GARUN (b), AVRUN (c), VIM climatology (d).

Interactive Discussion 
BGD

4, 909-959, 2007

\section{Mediterranean \\ sensitivity to atmospheric inputs}

M. Pacciaroni and G. Crispi

\section{Title Page}

\section{Abstract}

Introduction

Conclusions

References

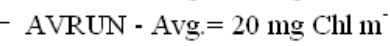

$--\mathrm{VIM}-\mathrm{Avg}=21 \mathrm{mg} \mathrm{Chl} \mathrm{\textrm {m } ^ { - 2 }}$

$20^{\circ} \mathrm{E}$

$30^{\circ} \mathrm{E}$

$35^{\circ} \mathrm{E}$

Longitude

Fig. 7. Vertically $(0-200 \mathrm{~m})$ integrated chlorophyll $\left(\mathrm{mg} \mathrm{Chl} \mathrm{m}^{-2}\right)$ along the zonal transect at $34^{\circ} \mathrm{N}$. NIRUN in open circles, GARUN in full line and AVRUN in dotted line, VIM climatology in dashed line. Averages along the zonal transect are reported in the legend.

\section{Tables}

14

Back

\section{Figures}

$>$ I

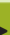

\section{Full Screen / Esc}

Printer-friendly Version 


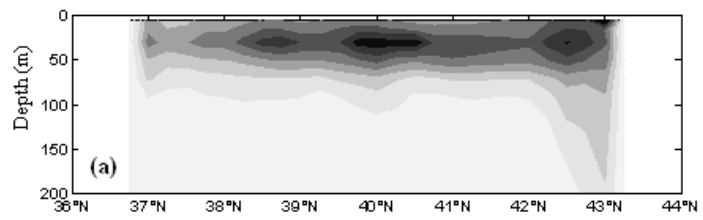

BGD

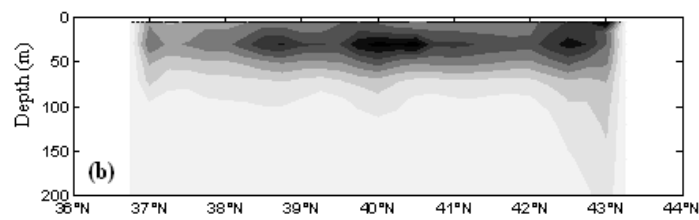

Mediterranean

sensitivity to atmospheric inputs

M. Pacciaroni and G. Crispi

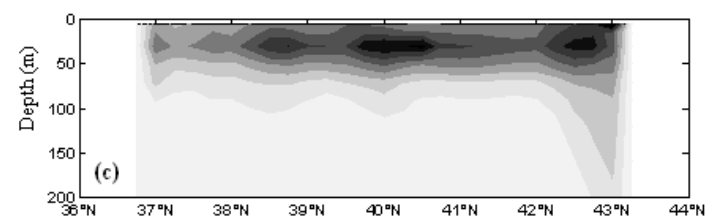

Title Page
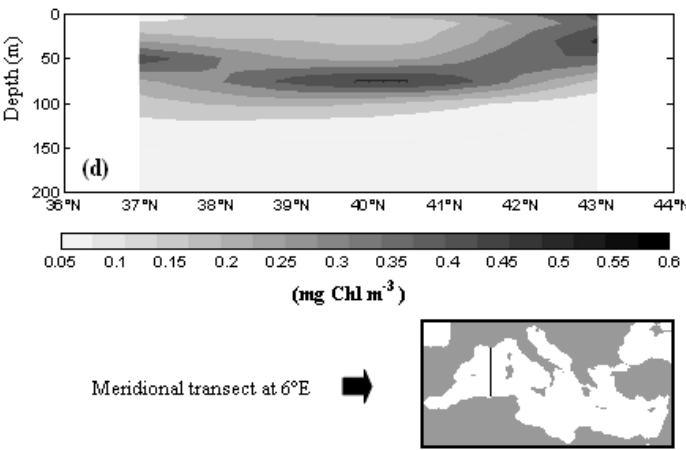

Fig. 8. Meridional transect of the yearly averaged chlorophyll $\left(\mathrm{mg} \mathrm{Chl} \mathrm{m}^{-3}\right)$ at $6^{\circ} \mathrm{E}$ in the western basin in the upper $200 \mathrm{~m}$. NIRUN (a), GARUN (b), AVRUN (c), VIM climatology (d). 
BGD

4, 909-959, 2007

\section{Mediterranean \\ sensitivity to \\ atmospheric inputs}

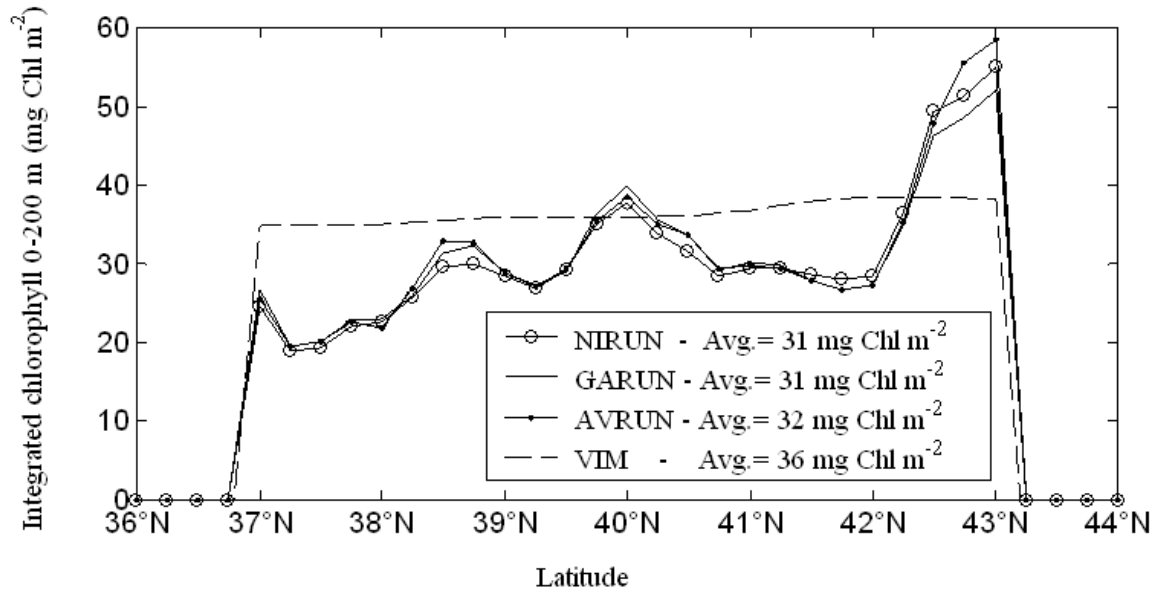

M. Pacciaroni and

G. Crispi

Title Page

Abstract

Introduction

Conclusions

References

Tables

Figures

14

$>1$

4

Back

Close

Full Screen / Esc

Printer-friendly Version

Interactive Discussion 
BGD

4, 909-959, 2007

\section{Mediterranean \\ sensitivity to atmospheric inputs}

M. Pacciaroni and G. Crispi

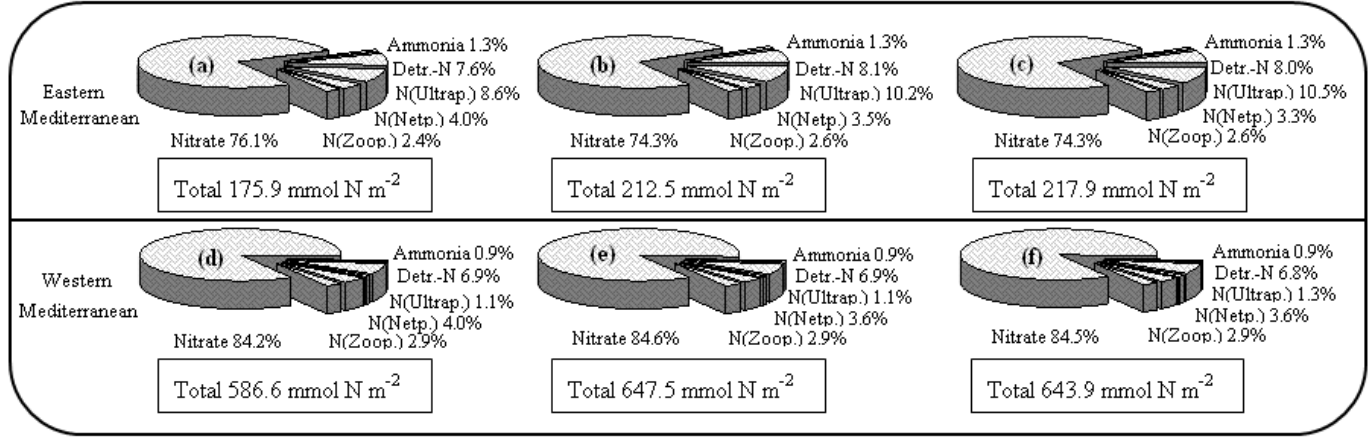

Fig. 10. Upper layer $(0-180 \mathrm{~m})$ nitrogen repartition among biochemical compartments with respect to total content indicated below each pie diagram. NIRUN respectively in the eastern and western basins (a)-(d), GARUN (b)-(e), AVRUN (c)-(f).
Title Page

Abstract Introduction

Conclusions References

Tables Figures

14

Back

Close

Full Screen / Esc

Printer-friendly Version

Interactive Discussion 
BGD

4, 909-959, 2007

\section{Mediterranean \\ sensitivity to atmospheric inputs}

M. Pacciaroni and G. Crispi

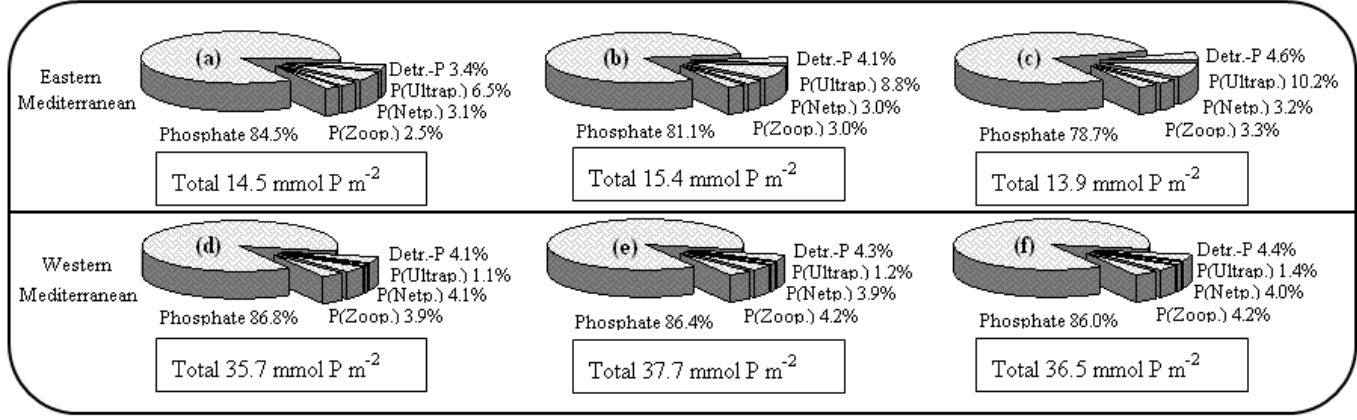

Fig. 11. Upper layer $(0-180 \mathrm{~m})$ phosphorus repartition among biochemical compartments with respect to total content indicated below each pie diagram. NIRUN respectively in the eastern and western basins (a)-(d), GARUN (b)-(e), AVRUN (c)-(f).
Title Page

Abstract Introduction

Conclusions

References

Tables

Figures

14

Back

Close

Full Screen / Esc

Printer-friendly Version

Interactive Discussion 
a)

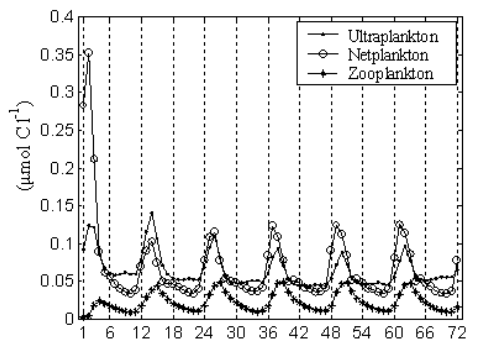

Time (months)

b)

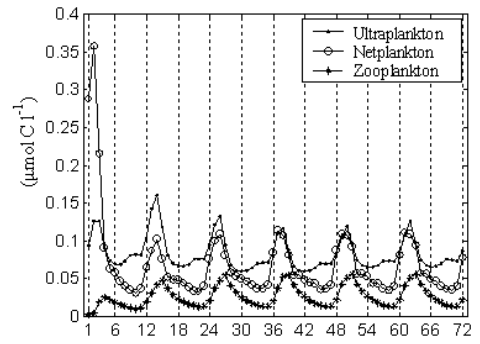

Time (months)

c)

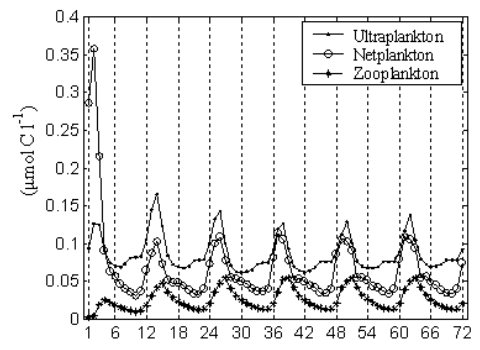

Time (months)
BGD

4, 909-959, 2007

\section{Mediterranean \\ sensitivity to atmospheric inputs}

M. Pacciaroni and G. Crispi

Title Page

Abstract Introduction

Conclusions

References

Tables

Figures

14

- I

4

Back

Close

\section{Full Screen / Esc}

Fig. 12. Time evolution of biological compartments $\left(\mu \mathrm{molC} \mathrm{dm}^{-3}\right)$ integrated all over the basin Printer-friendly Version for 6 years in the case of NIRUN (a), GARUN (b) and AVRUN (c). Ultraplankton, full points, netplankton, open circles, zooplankton, star points.

Interactive Discussion 